\title{
Application of paleoseismological techniques to the study of Late Pleistocene-Holocene deep-seated gravitational movements at the Mortirolo Pass (central Alps, Italy)
}

\section{Onida ${ }^{1}$, F. Galadini ${ }^{2}$, F. Forcella ${ }^{3}$}

1 Corresponding author; Dipartimento di Scienze della Terra, Università degli Studi di Milano, via Mangiagalli 34, I-20133, Milano, Italy (e-mail: Monica.Onida@unimi.it)

2 CNR, Istituto di Ricerca sulla Tettonica Recente, Area di Ricerca di Roma-Tor Vergata, via del Fosso del Cavaliere, I-00133, Roma, Italy (e-mail: galad@irtr.rm.cnr.it)

3 Dipartimento di Scienze della Terra e Geotecnologie, Università degli Studi di MilanoBicocca, Italy; CNR, Centro di Studio per la Geodinamica Alpina e Quaternaria, Milano, Italy.

Manuscript received: July 2000; accepted: April 2001

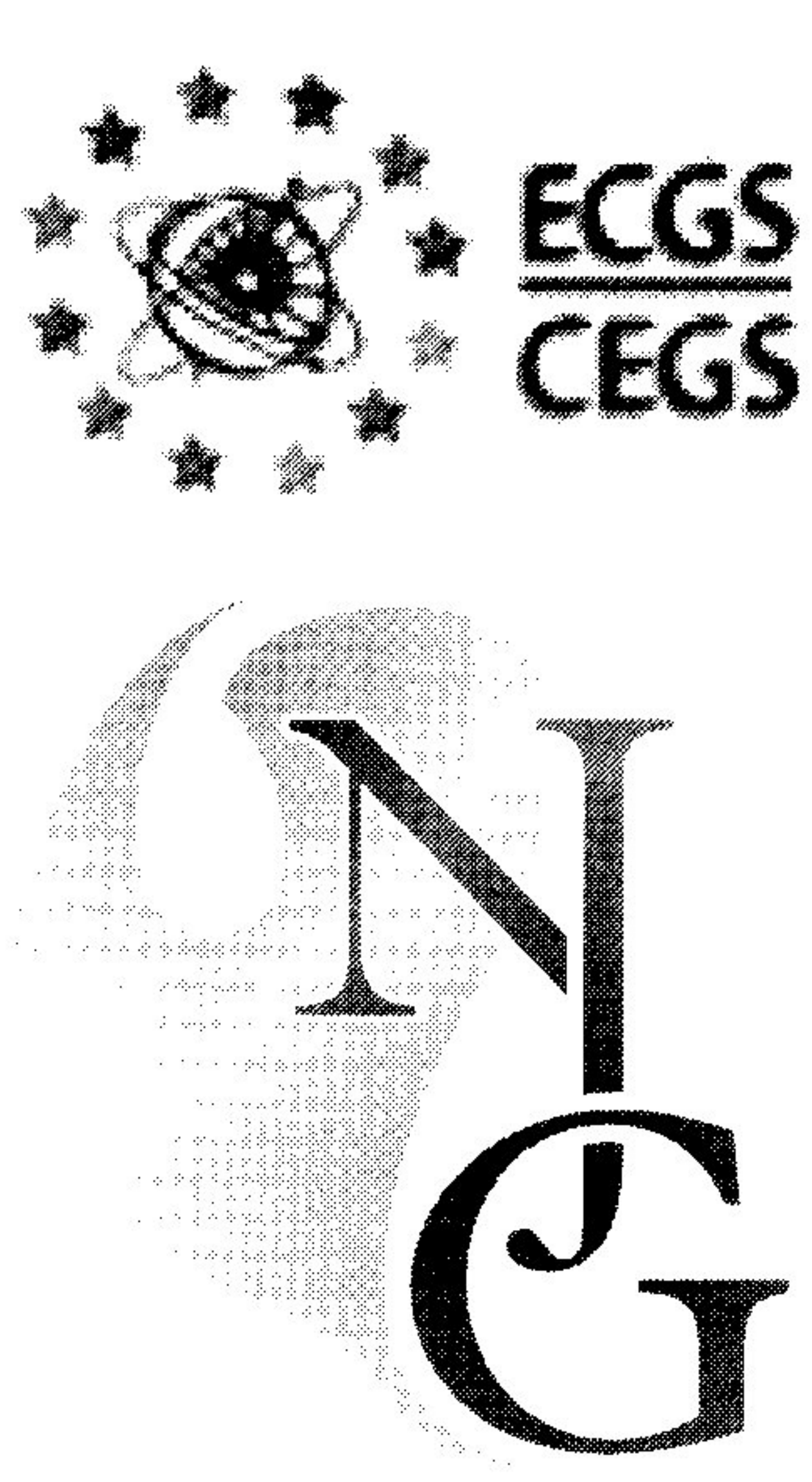

\begin{abstract}
Paleoseismological techniques have been used to investigate gravitational deformations at the Mortirolo Pass (Valtellina region, central Alps), in order to improve the knowledge on the activation mechanisms and the evolution of deep-seated gravitational slope movements. The deformation has been responsible for mass sliding towards the Valtellina depression through the activation of several-hundred-metre-long shear planes. Minor shear planes dipping towards the mountain played the role of antithetic structures. Four trenches were excavated across scarps representing the surficial expression of shear planes affecting the bedrock and Late Pleistocene-Holocene deposits. The excavations enabled to investigate the stratigraphy of Quaternary deposits and the geometry and kinematics of the shear planes affecting them. Radiocarbon analyses on organic material contained in sediments and paleosols enabled to define a succession of displacement events which occurred during the Late Pleistocene-Holocene. Collected data indicate the persistence of the activity until recent times (last movement related to 1810-1540 cal. BP). A sudden movement has been detected along one of the main shear surfaces (dipping towards the valley) with a vertical displacement of several metres. In contrast, numerous displacements (with lower vertical offset) have been detected along the antithetic shear planes. Different hypotheses have been proposed in the past to define the origin of huge gravitational movements (glacial retreat, uplift of the Alpine chain, fault activity). However, the Late Pleistocene cycles of glacial loading and unloading on the mountain slopes seem to be the most probable factors causing deep-seated gravitational movements in the investigated region. A recent dramatic landslide in an area adjacent to the investigated one (Mt. Zandila-Valpola) testifies to the paroxistic evolution of the large scale gravitational deformations. The densely inhabited Valtellina region is affected by a large number of gravitational structures similar to those of the Mortirolo area. In consideration of the possible effects of the paroxistic activation of these structures, detailed studies on the chronology and kinematics of the deformations through the application of paleoseismological techniques should therefore be encouraged.
\end{abstract}

Keywords: deep-seated gravitational deformation, Holocene deformation, paleoseismological techniques, central Alps

\section{Introduction}

Gravitational mass movements and related geomorphic features are widespread along mountain slopes and ridges of the upper Valtellina region (Central Alps, Italy). In particular, a 15-km-long deep-seated gravitational slope deformation affects the SE slope of the Adda valley, between Tirano and Grosio (Fig.1; Forcella, 1984).

The surficial expressions of the shear planes mostly consist of downhill- and uphill-facing scarps, linear troughs, ground fissures, and double-crested ridges. Similar landforms result from gravitational spreading of mountain ridges and are interpreted as the surface evidence of deep-seated slope movements (Zischinsky, 1966; Beck, 1968; Radbruch-Hall et al., 1976; Forcella, 1984; Mortara \& Sorzana, 1987; Dramis \& Sorriso-Valvo, 1994; Sorriso-Valvo, 1995). However, if the geomorphic expression of such kind of deformations is well known and described for a large num- 
ber of cases in mountainous areas, knowledge on other aspects is still sparse. One of the main problems is the kinematics of the deformations, in particular the timing of the displacements and whether they occur through slow or sudden movements (or both) along the shear planes. Moreover, the long-term evolution of deformations involving entire mountain ranges has not been completely understood and therefore no data which may be suitable in hazard evaluations are available. Finally, the relationship between large mass movements of gravitational origin and tectonic activity has only been addressed in the past from a qualitative point of view.

We tried therefore to collect data on the kinematic characteristics and on the evolution of the deformation processes at the Mortirolo Pass through the excavation of four trenches across scarps indicating a recent (Late Pleistocene-Holocene) activation of shear planes. This technique, usually adopted in paleoseismological works, has already been tested for the study of gravitational movements in the Central Alps (Forcella et al., 1998) and elsewhere (McCalpin \& Irvine, 1995).

After the description of the geomorphic features related to recent displacements along the SE slope of the Adda valley, the trenching results will be analysed. Gathered data enabled to make some hypotheses on the chronology of the deformation, on the kinematics of the displacements responsible for the formation of downhill- and uphill- facing scarps and on the triggering factors.

\section{Geological framework}

The investigated deformations affect an area located just north of the Insubric fault, a major tectonic boundary of Alpine age separating the N- and NWverging Alpine Nappe systems and the Southalpine Sverging fold-and-thrust belt. The rocks outcropping in the investigated area belong to the so-called Campo Nappe, a tectonic unit which is part of the middleupper Austroalpine Nappe system of the Central Alps (Fig. 1; Froitzheim et al., 1994) and comprises low to medium grade metamorphic rock assemblages of Variscan age.

The Mt. Tonale Gneiss, the Cima Rovaia Micaschists and the Punta di Pietra Rossa Schist Fms. can be detected from the southern towards the northern part of the investigated area. Gneisses and amphibolites are intercalated with schists; marble intercalations are also present, particularly in the southern part (close to the Insubric Fault: Motto della Scala, Mt. Padrio). The regional lithological boundaries, the Variscan metamorphic foliation and the brittle fault

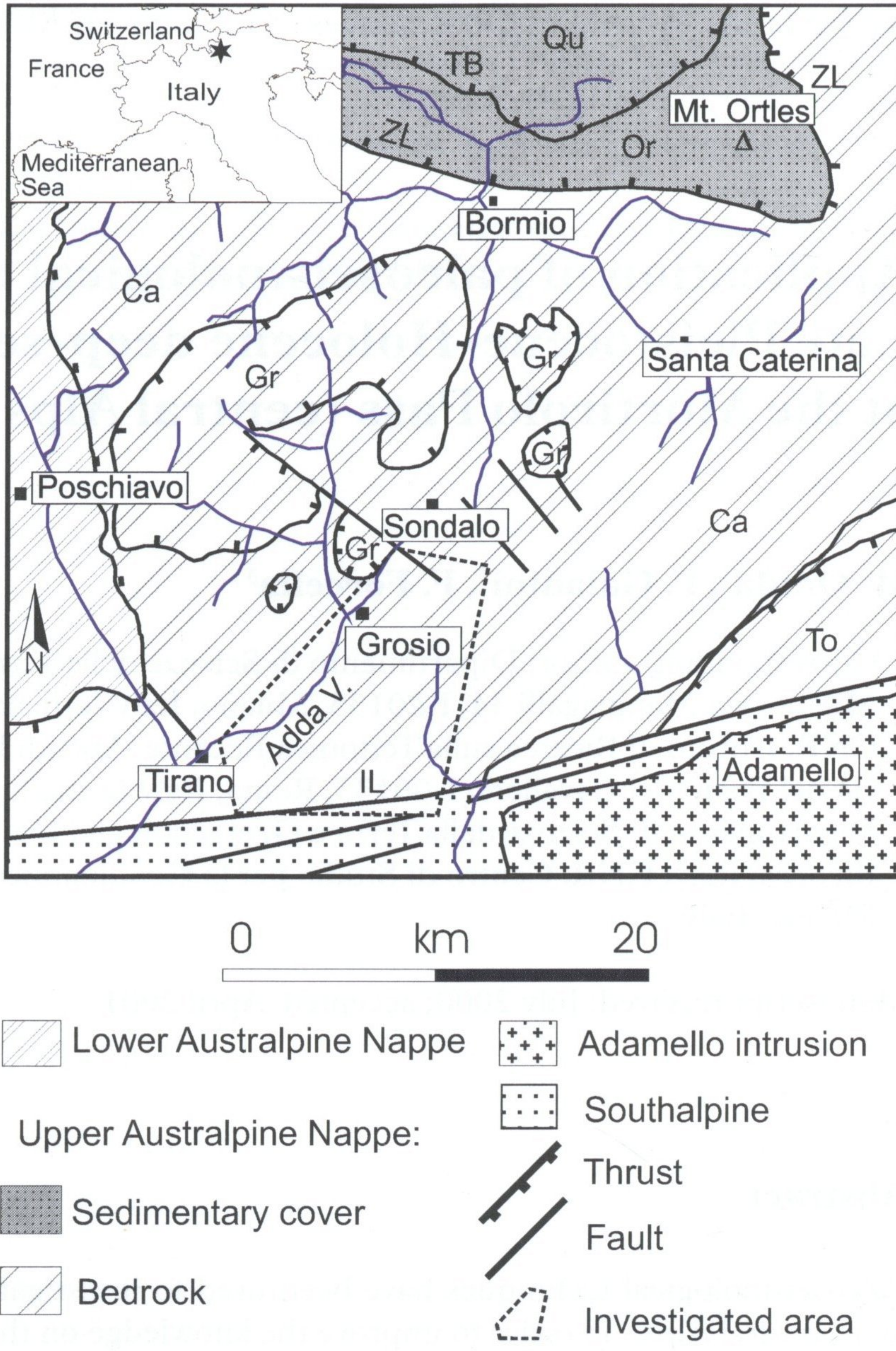

Fig. 1. Schematic location and geological map of the investigated area. Legend: Ca, Campo Nappe; Gr, Grosina Nappe; Or, Ortles Nappe; Qu, Quattervals Nappe; To, Monte Tonale Gneiss; ZL, Zebrù Line; IL, Insubric Line; TB, Trupchun-Braulio thrust (from Forcella et al., 1998, modified).

zones of late Alpine age are WSW-ENE trending, i.e. they are parallel to the Insubric fault.

According to Laubscher (1988), the Insubric fault was affected by dextral transcurrent activity during the Oligocene and in the Early Neogene. During this period the fault accommodated a total displacement of several tens of kilometres. The occurrence of Cretaceous-Paleogene displacements along this structure is still debated in the literature; the activity of the Insubric fault, however, probably ended when movements along the crosscutting Giudicarie sinistral fault-zone began (Late Neogene times; Castellarin et al., 1987). Therefore the Insubric fault is presently considered as inactive.

During the Neogene until the Present the whole Alpine area experienced a significant uplift which, together with the Late Messinian drying up of the Mediterranean Sea (Bini et al., 1978), was responsible for the excavation of the valleys on the southern side of the Alps (Finck, 1978; Felber et al., 1991).

The present landscape of the investigated area 
mainly resulted from the geomorphic modelling due to the erosional and depositional activity during the Late Pleistocene glacial advancements and retreats. Therefore, outcropping Quaternary deposits and related landforms are generally not older than few tens of thousand years. The displacement of such landforms and deposits demonstrates the young age of the slope deformations at the Mortirolo Pass.

The investigated area is almost aseismic: no large earthquakes are recorded in the available catalogues (e.g. Working Group CPTI, 1999, reporting earthquakes since $217 \mathrm{BC}$ ) and only a minor seismicity (events not larger than $M=4.9$ ) affects areas north of the Mortirolo Pass (Onida et al., 2000 and references therein).

\section{Geomorphological evidence of recent movements}

Downhill- and uphill-facing scarps, multiple crests and open fissures have been detected along the left flank of the Adda river valley at an elevation of 1700$2100 \mathrm{~m}$ (Mortirolo Pass area) close to the top of the Mt. Padrio-Mt. Varadega ridge (Figs. 2 to 4). These geomorphic features affect both the metamorphic bedrock and Late Pleistocene-Holocene deposits along a NE-SW (locally E-W and N-S) trending, 15$\mathrm{km}$-long, 1-km-wide deformation belt.

The recent activity along the shear planes which are responsible for the deformation of the slope was already documented by Forcella (1984), who interpreted the observed geomorphic features as the result of sackung-type displacements, based on the similarity with other cases reported in the literature (e.g. Radbruch-Hall et al., 1976).

The southern boundary of the deformation belt (in the Mt. Padrio area) is close to the Insubric fault, but it progressively departs from this fault towards the north (Motto della Scala-Mt. Varadega), and is controlled by the local trend of the Adda valley. The ridge is crossed by wide saddles along which the transfluence of glacial tongues occurred during the Last Glacial Maximum (L.G.M., 20,000-18,000 BP; e.g. Orombelli, 1983). Close to these saddles the scarps cluster and form interference patterns.

A description of the geomorphic features resulting from the recent activation of the shear planes affecting the southern slope of the Adda valley is proposed below.

\section{Downhill-facing scarps}

Downhill-facing scarps are mostly concentrated in the upper part of the slope and along the wathershed.
Single scarps are up to $2 \mathrm{~km}$ long and N-S to NNESSW (locally WSW-ENE) trending.

Two to four, up to 20-30-m-high scarps can be identified along a section perpendicular to the Mt. Varadega-Motto della Scala ridge. The multiple crested ridge, with 20-60-m-wide linear depressions, represents a typical sackung landform. The formation of the downhill-facing scarps is due to movements along shear surfaces dipping towards the valley. The length and height of the scarps indicate that the most significant displacements occurred along these shear planes, they must therefore be considered as the main structures affecting the left slope of the Adda valley.

\section{Uphill-facing scarps}

These features are widespread in the investigated area, particularly in the middle-upper part "of the slope, at an elevation lower than that of the downhillfacing scarps. The entire scarp system forms a 30-to500-m-wide deformation zone. Uphill-facing scarps are usually $0.5-3 \mathrm{~m}$ high, $100-500 \mathrm{~m}$ long and cross the slope slightly obliquely. Moreover, they bound linear troughs and closed depressions up to $10 \mathrm{~m}$ wide. The scarps and the related shear planes are bent in plan view in the areas where saddles interrupt the continuity of the ridge. This suggests that the pre-existing morphology, mainly resulting from the L.G.M. period, conditioned the development of these recent scarps. Moreover, the scarps cluster in the saddle areas and the interference pattern between differently oriented shear planes is responsible for rhomboidal geometries in plan view (Fig. 2).

The shear planes dipping towards the mountain were responsible for the formation of uphill-facing scarps whose height is definitely lower than that of the downhill-facing scarps. This suggests lower vertical offsets along the related shear planes.

\section{Open fissures}

Several open fissures, usually subvertical, in few cases with a low dip, mainly affect the flat saddle areas. The along-strike length ranges between 1 and $20 \mathrm{~m}$, the depth between 2 and $5 \mathrm{~m}$ and the opening between 0.2 and $3 \mathrm{~m}$. Some of the fissures are aligned in prolongation of the uphill-facing scarps. Extension perpendicular to the slope was responsible for the formation of these features. In some cases the fissures have been filled by colluvial material, as observed in some trenches (see below). 


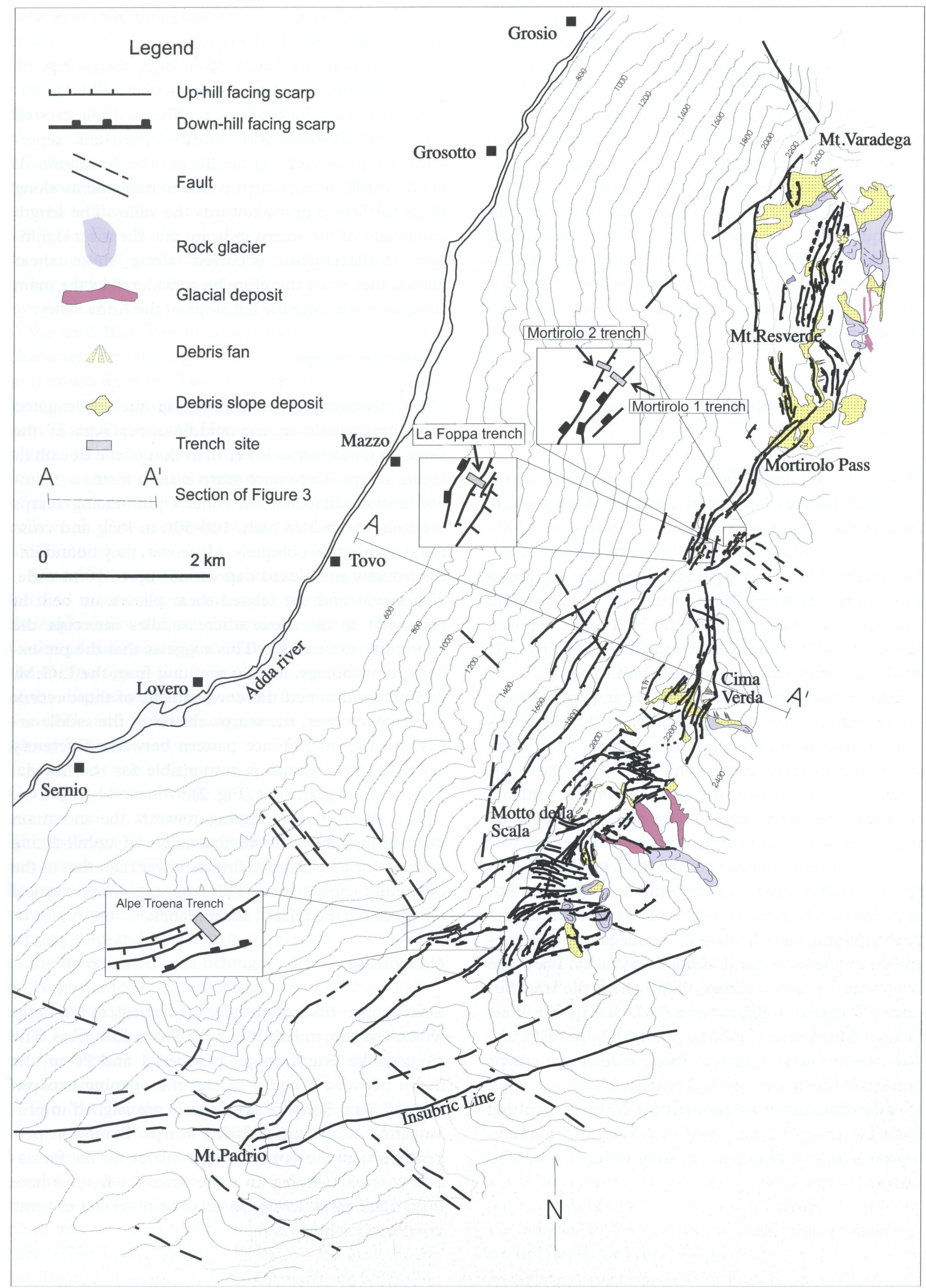

Fig. 2. Morphostructural map of the Mortirolo Pass area. 


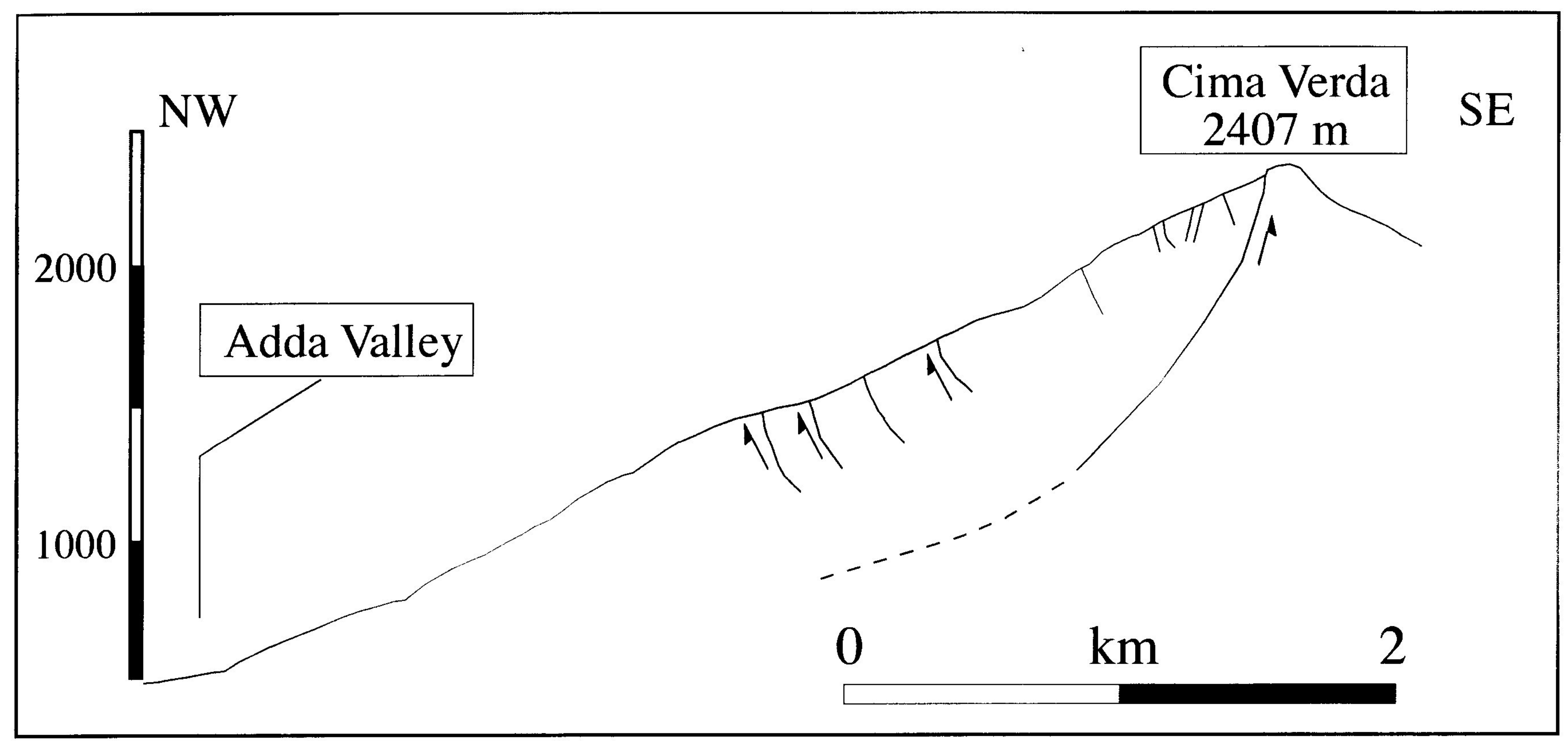

Fig. 3. Topographic and structural section across the SE slope of the Adda valley (see Fig. 2 for location). The shear planes responsible for the formation of uphill- and downhill-facing scarps have been reported.

\section{Paleoseismological analysis}

Four trenches have been excavated in order to investigate the recent displacements suggested by the above described geomorphic features. Three trenches were made across uphill-facing scarps and one across a downhill-facing scarp. The trench analysis allowed us to define the subsurface geometry of the shear planes, to evaluate the vertical offset, to recognise the occurrence of displacement events and to date the activity by means of radiocarbon analyses. Subvertical to steeply dipping shear surfaces affecting both the bedrock and young sediments were observed in all the trenches. Shear planes are easily detectable where the bedrock is in contact with Quaternary deposits. They are less well defined when they only affect unconsolidated sediments. In the former case, the displacement inside young sediments can be inferred by observing shear textures at the contact with the bedrock. In the latter case, deformations are suggested by rotations and alignments of clasts along narrow zones parallel to the shear planes or by vertical sharp contacts between deposits of different facies.

The deposits observed in the trenches mainly consist of massive silts, sandy silts, fine and coarsegrained sands, sandy gravels and gravels. As for the facies, they are mainly slope deposits, debris flow accumulations and colluvial units, derived from the ero-

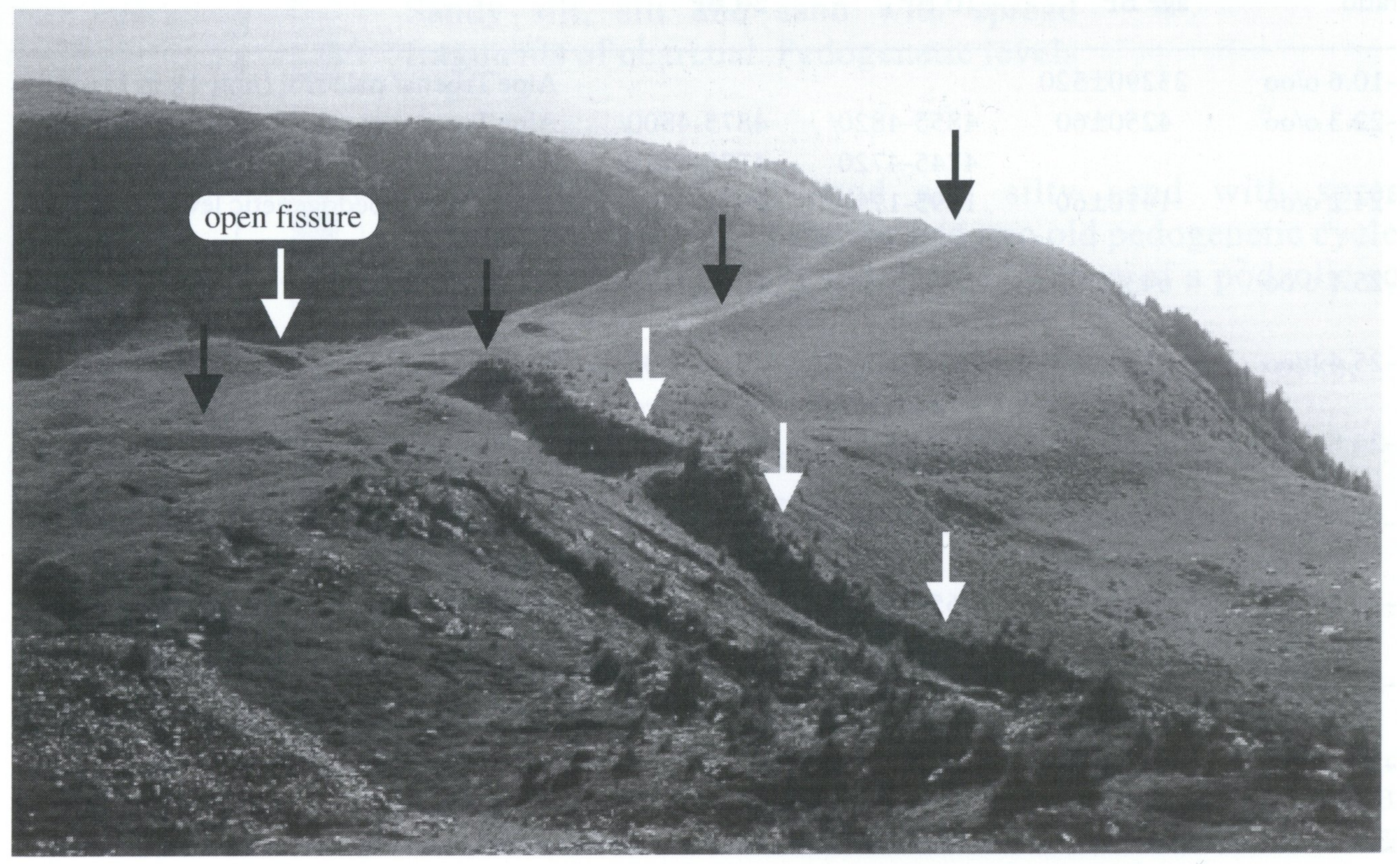

Fig. 4. View of the uphill-facing scarps affecting the Motto della Scala-Dosso San Giacomo area. Scarps trending both NNE-SSW (white arrows) and ENE-WSW (black arrows) can be observed. 
sion of the metamorphic bedrock or re-deposition of Quaternary sediments. Glacial deposits, pond and marsh sediments and rare lenses of well-sorted sands and gravels (suggesting sheet flow deposition) are also present.

Well-developed podzol soils rich in organic matter are buried at different stratigraphic levels; their presence is consistent with the periglacial environment that affected the area during the Late PleistoceneHolocene. Podzol soils generally develop in cool and wet conditions, with water seeping through the ground and carrying downward the organic matter leached from the upper levels. An acid bedrock and a consistent vegetation are considered as conditions favourable to the formation of this kind of soils (Cremaschi \& Rodolfi, 1991).

The ages of the stratigraphic units detected in the trenches (and therefore chronological constraints for the displacements affecting them) have been obtained by means of the radiocarbon datings reported in Table 1.

Paleosols, charcoal levels and sediments rich of organic matter have been analysed by Beta Analytic (Miami, Florida). All the samples provided carbon for accurate radiometric analyses. The obtained conventional ages (if more recent than 19,000 BP) have been calibrated in the mentioned laboratory by using the INTCAL98 database reported in Stuiver et al. (1998). Ages reported in the text represent the 2 Sigma calibrated results (95\% of probability).

\section{Alpe Troena site}

This trench, $14 \mathrm{~m}$ long and up to $4 \mathrm{~m}$ deep, has been excavated close to the Alpe Troena site (see Fig. 2 for location), across a $\mathrm{N} 45^{\circ}$-trending, 1.5-m-high, 100$\mathrm{m}$-long uphill-facing scarp, at an altitude of $1900 \mathrm{~m}$ (Figs. 5 and 6).

The weathered metamorphic bedrock was exposed in the NW portion of the trench, where a paleosol (unit 12) overlying the bedrock has been radiocarbon dated at $23290 \pm 520 \mathrm{BP}$. This date indicates that a pedogenetic phase affected the investigated area before the L.G.M. glacial cover. A similar soil has also been found in the SE portion of the trench (unit 13). A glacial till (unit 11) related to the L.G.M., and a succession of other paleosols, colluvial and slope deposits overlie the mentioned Late Pleistocene paleosols.

The lower part of the post-L.G.M. sequence (units 5-9) is made of gravels, coarse sands, sands and siltysands with spread fragments of charcoal (Fig. 6).

A complete pedological cycle has been recognised inside these units: unit 9 represents a spodic horizon (radiocarbon dated at $4875-4800 / 4770-4580 \mathrm{cal}$. BP) that has been partially eroded and deposited in the lower part of the depression; unit 7 is the eluvial horizon, only preserved in two minor lenses; unit 6 represents the organic horizon and overlies the previously described units.

Unit 5, only exposed in the central part of the investigated section, is bounded towards the NW by a

Table 1. Radiocarbon dates of samples collected in the trenches excavated at the Mortirolo Pass area. R, radiometric technique; BLC, bulk/low carbon material procedure; AMS, accelerator mass spectrometry technique.

\begin{tabular}{|c|c|c|c|c|c|c|}
\hline $\begin{array}{l}\text { Lab. code } \\
\text { Beta - }\end{array}$ & Analysis & $\begin{array}{l}\mathrm{C} 13 / \mathrm{C} 12 \\
\text { ratio }\end{array}$ & $\begin{array}{l}\text { Conventional } \\
\text { age } \mathrm{BP}\end{array}$ & $\begin{array}{l}\text { Calib. age } \\
1 \sigma \mathrm{BP}\end{array}$ & $\begin{array}{l}\text { Calib. age } \\
2 \sigma \mathrm{BP}\end{array}$ & Location/Sample description \\
\hline 123847 & $\mathrm{R}, \mathrm{BLC}$ & $-10.6 \mathrm{o} / \mathrm{oo}$ & $23290 \pm 520$ & & & Alpe Troena/ paleosol (unit 12 in Fig. 6) \\
\hline 123846 & $\mathrm{R}, \mathrm{BLC}$ & $-22.3 \mathrm{o} / \mathrm{oo}$ & $4250 \pm 60$ & $\begin{array}{l}4855-4820 / \\
4745-4720\end{array}$ & $\begin{array}{l}4875-4800 / \\
4770-4580\end{array}$ & $\begin{array}{l}\text { Alpe Troena/ spodic horizon of a podzol } \\
\text { soil (unit } 9 \text { in Fig. } 6 \text { ) }\end{array}$ \\
\hline 123845 & $\mathrm{R}, \mathrm{BLC}$ & $-24.2 \mathrm{o} / \mathrm{oo}$ & $1910 \pm 60$ & $1895-1790$ & $1970-1705$ & $\begin{array}{l}\text { Alpe Troena/ pedogenetic level (unit } 4 \text { in } \\
\text { Fig. 6) }\end{array}$ \\
\hline 133150 & AMS & $-25.1 \mathrm{o} / \mathrm{oo}$ & $6430 \pm 60$ & $7425-7280$ & $7440-7250$ & $\begin{array}{l}\text { La Foppa/ sandy-silty colluvium (unit } 12 \\
\text { in Fig. 9) }\end{array}$ \\
\hline 133151 & $\mathrm{R}, \mathrm{BLC}$ & $-25.4 \mathrm{o} / \mathrm{oo}$ & $4120 \pm 60$ & $\begin{array}{l}4815-4745 / \\
4720-4530\end{array}$ & $4835-4435$ & $\begin{array}{l}\text { La Foppa/ spodic horizon of a podzol } \\
\text { soil (unit } 6 \text { in Fig. 9) }\end{array}$ \\
\hline 133147 & $\mathrm{R}$ & $-24.8 \mathrm{o} / \mathrm{oo}$ & $2460 \pm 80$ & $2730-2355$ & $2755-2335$ & $\begin{array}{l}\text { La Foppa/ organic horizon of a podzol soil } \\
\text { (unit } 3 \text { in Fig. 9) }\end{array}$ \\
\hline 133148 & $\mathrm{R}, \mathrm{BLC}$ & $-24.5 \mathrm{o} / \mathrm{oo}$ & $1500 \pm 60$ & $1420-1320$ & $1525-1295$ & $\begin{array}{l}\text { Mortirolo } 1 / \text { organic silt (unit } 10 \text { in } \\
\text { Fig. 12) }\end{array}$ \\
\hline 133145 & $\mathrm{R}, \mathrm{BLC}$ & $-26.2 \mathrm{o} / \mathrm{oo}$ & $660 \pm 60$ & $\begin{array}{l}665-625 / \\
605-555\end{array}$ & $690-540$ & Mortirolo 1/ organic silt (unit 2 in Fig. 12) \\
\hline 133146 & $\mathbf{R}$ & $-25.9 \mathrm{o} / \mathrm{oo}$ & $1510 \pm 70$ & $1505-1320$ & $1540-1290$ & $\begin{array}{l}\text { Mortirolo 2/ organic horizon of a podzol } \\
\text { soil (unit } 3 \text { in Fig. 15) }\end{array}$ \\
\hline 133149 & $\mathrm{R}, \mathrm{BLC}$ & $-25.2 \mathrm{o} / \mathrm{oo}$ & $1750 \pm 50$ & $1715-1585$ & $1810-1540$ & $\begin{array}{l}\text { Mortirolo 2/ sandy-silty colluvium (unit } 5 \\
\text { in Fig. 15) }\end{array}$ \\
\hline
\end{tabular}




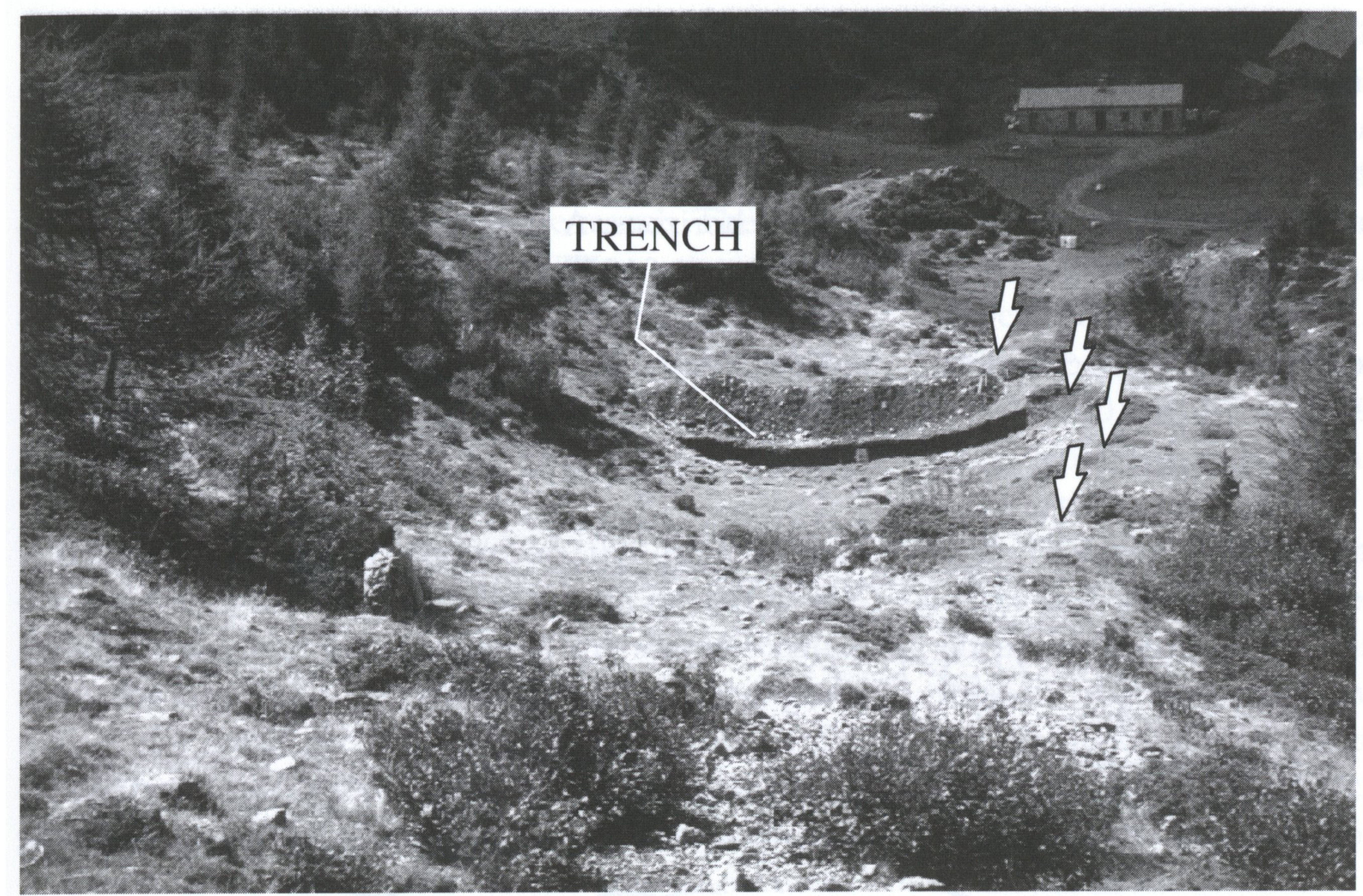

Fig. 5. View of the ENE-WSW uphill-facing scarp at the Alpe Troena site and location of the trench.

NW
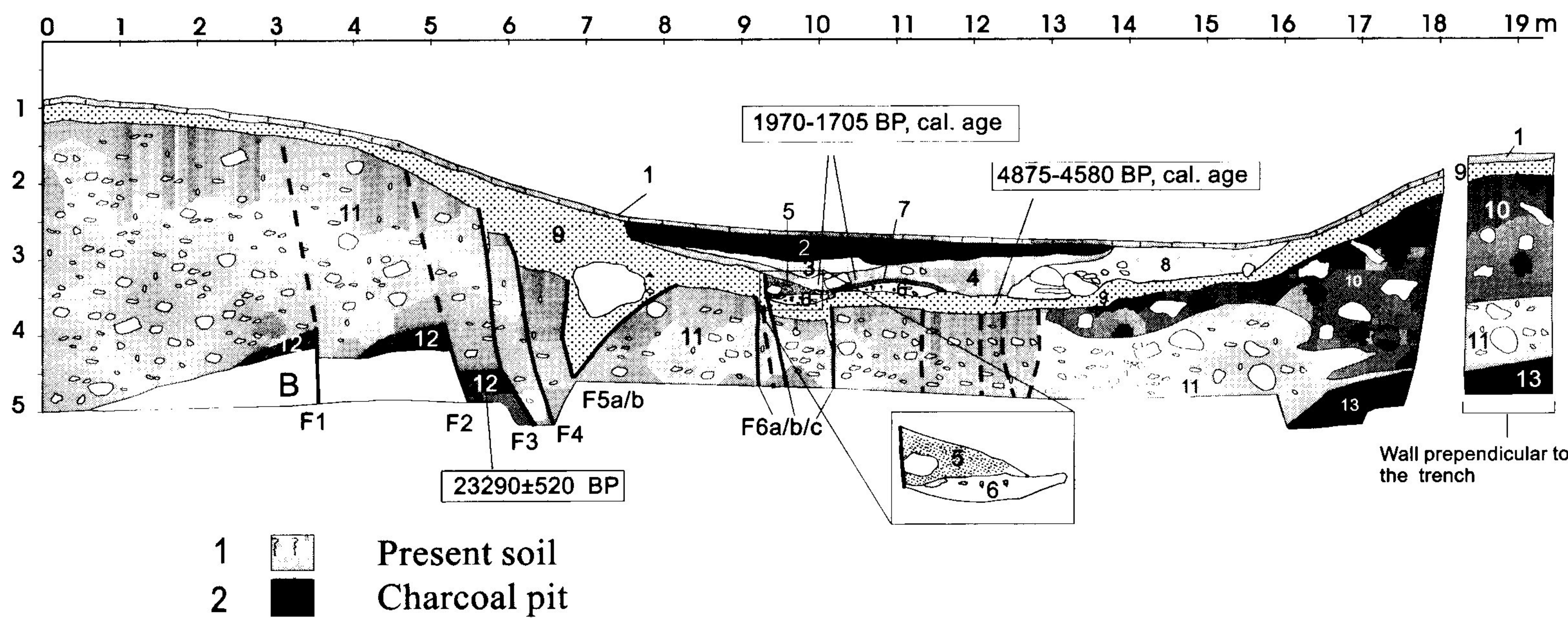

$3 \square$ Sandy silt, silt and sand with spread

$4 \square$ fragments of charcoal. Pedogenetic levels

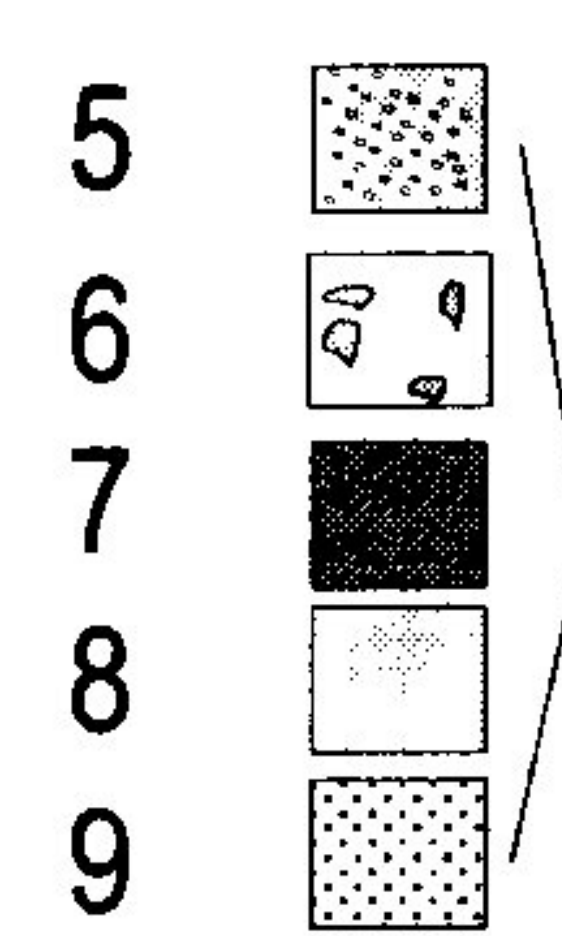

Gravel, coarse sand, sand and silty sand with spread fragments of charcoal belonging to two old pedogenetic cycles. Colluvial wedge (unit 5) and spodic horizon of a podzolic soil

Silty sand, with several large blocks of metamorphic rocks,

105 - strongly or completely weathered

11 Massive and heterogeneous sandy gravel of glacial origin

12 Massive silty sand: paleosol

$13 \square$ Massive sand: paleosol

B $\square$ Metamorphic bedrock

F1-6// Shear planes

Fig. 6. Log of the trench (NE wall) excavated at the Alpe Troena site. Two displacement events have been detected at this site: the oldest occurred between $23290 \pm 520 \mathrm{BP}$ and $4875-4800 / 4770-4580$ cal. BP or alternatively between $23290 \pm 520 \mathrm{BP}$ and the L.G.M. (about 20000$18000 \mathrm{BP}$ ), while the youngest event occurred between $4875-4800 / 4770-4580 \mathrm{cal}$. BP and 1970-1705 cal. BP. 
subvertical shear plane and is made of massive sandygravels partially pedogenised, with charcoal fragments. Due to the sedimentological characteristics and the triangular shape observed in the section, this unit has been interpreted as a colluvial wedge, fed by a scarp formed with the activation of the F6c shear plane.

The upper portion of the sequence (units 3 and 4 ) is made of undeformed sandy-silts, silts and sands with spread fragments of charcoal; three pedological cycles can be distinguished in this sequence due to the presence of few-cm-thick organic, eluvial and spodic horizons. A sample from unit 4 gave a radiocarbon age of 1970-1705 cal. BP.

Two displacement events or phases have been detected at the Alpe Troena site (Fig. 7).

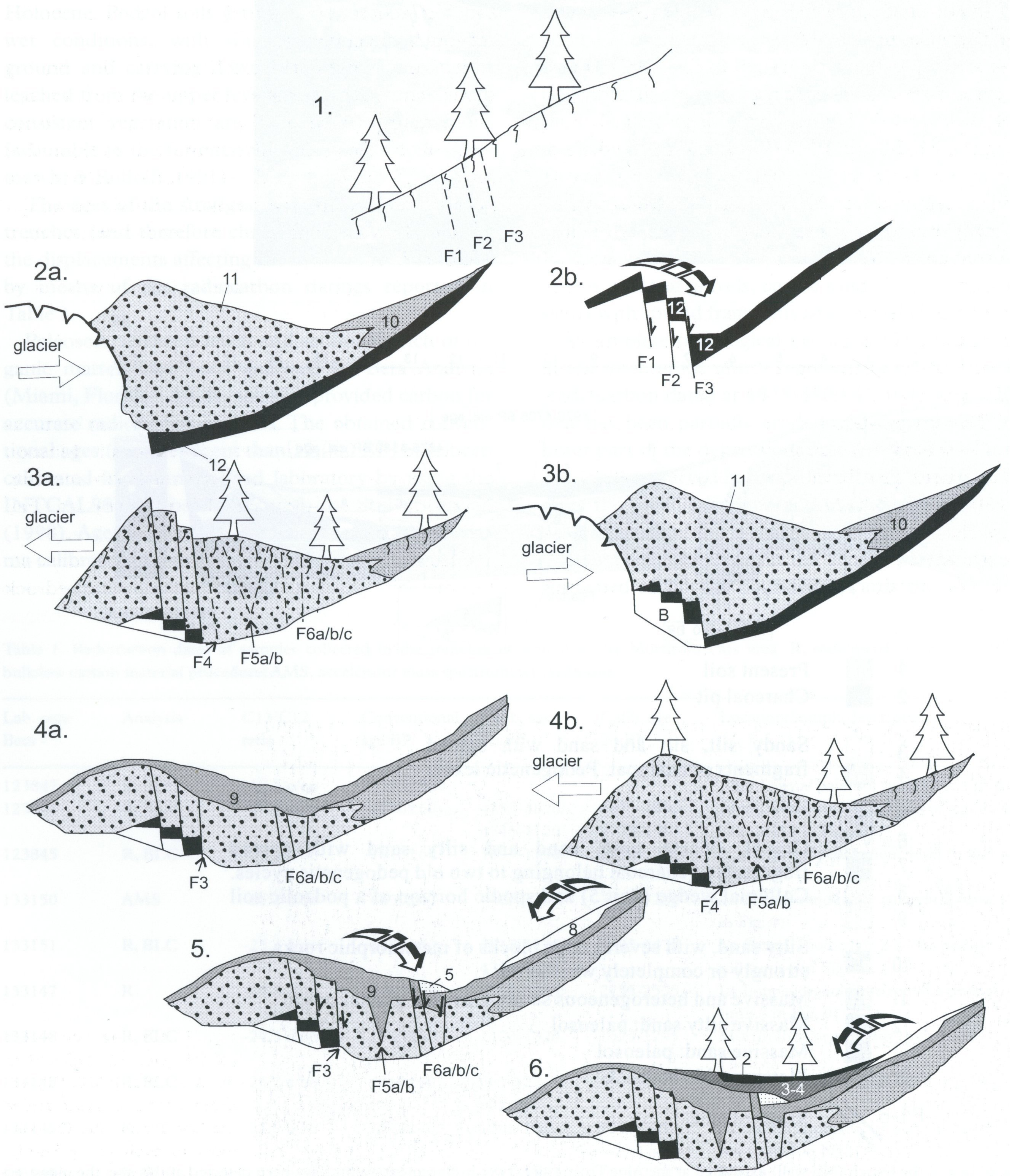

Fig. 7. Evolution of the deformation at the Alpe Troena site (see text for explanation). Fn, shear planes as reported in Fig. 6. Unit numbering as in Fig. 6. 
The youngest occurred between 4875-4800/47704580 cal. BP (unit 9) and 1970-1705 cal. BP (unit 4), as shown by the displacement of units 11 and 9 before the deposition of unit 4 which seals the shear plane F6b in the central part of the trench. The oldest event can be detected in the NW portion of the trench through the offset of the paleosol (unit 12) dated at $23290 \pm 520 \mathrm{BP}$ (Fig. 8) and occurred before the deposition of unit 9 (4875-4800/4770-4580 cal. $\mathrm{BP}$ ) whose base is affected by a vertical offset lower than that affecting unit 12 .

According to this interpretation, the displacement occurred after the deposition of the till related to the L.G.M. (unit 11). The erosion of the scarps formed along the F1, F2 and F3 shear planes fed the deposition of the lower part of unit 9 , which subsequently experienced pedogenesis and further displacement probably during the above mentioned younger event.

Alternatively, the oldest displacement occurred along the F1, F2 and F3 shear planes after the formation of the paleosol (unit 12) but before the deposition of the L.G.M. till (unit 11). The preservation of the offset affecting the top unit 12 may have been due to the glaciated condition of the paleo-ground surface. The scarps may have, therefore, been buried under the till (unit 11). According to this hypothesis, the displacement may have occurred between $23290 \pm$ $520 \mathrm{BP}$ and the L.G.M.

On the basis of the available data we can hypothesise two alternative site histories (Fig. 7):

A: 1), 2a) a paleosol dated at $23290 \pm 520 \mathrm{BP}$ (unit
12) developed along the slope and was buried under the L.G.M. glacial till related to a lateral moraine (unit 11); 3a) the paleosol and the glacial till were displaced by the F1, F2, F3 shear planes; 4a) the scarps affecting the glacial till were eroded and the deposition of unit 9 occurred in a colluvial facies; 5) unit 9 experienced pedogenesis; a podzol soil formed, and was subsequently displaced (between 4875-4800/ 4770-4580 cal. BP and 1970-1705 cal. BP); 6) further deposition (units 4 and 3) was responsible for sealing the shear planes.

B: 1) a paleosol dated at $23290 \pm 520 \mathrm{BP}$ (unit 12) developed along the slope; $2 \mathrm{~b}$ ) this paleosol experienced a first phase of displacement and moderate erosion; 3b) the glacial advancement was responsible for the deposition of glacial till (unit 11) related to a lateral moraine; $4 \mathrm{~b}$ ) the changed climatic condition permitted the beginning of pedogenetic processes, 5 and 6) as in A.

Finally, human activities are indicated by the presence of a charcoal pit (unit 2).

\section{La Foppa site}

This trench, $12 \mathrm{~m}$ long and 2-3 $\mathrm{m}$ deep, has been excavated at the La Foppa site (1800 m of altitude), close to the Mortirolo Pass, across a N $35^{\circ}$-trending, 1.5-m-high, 200-m-long, uphill-facing scarp (see Fig. 2 for location).

Glacial, lacustrine, alluvial and colluvial deposits together with the unweathered metamorphic bedrock

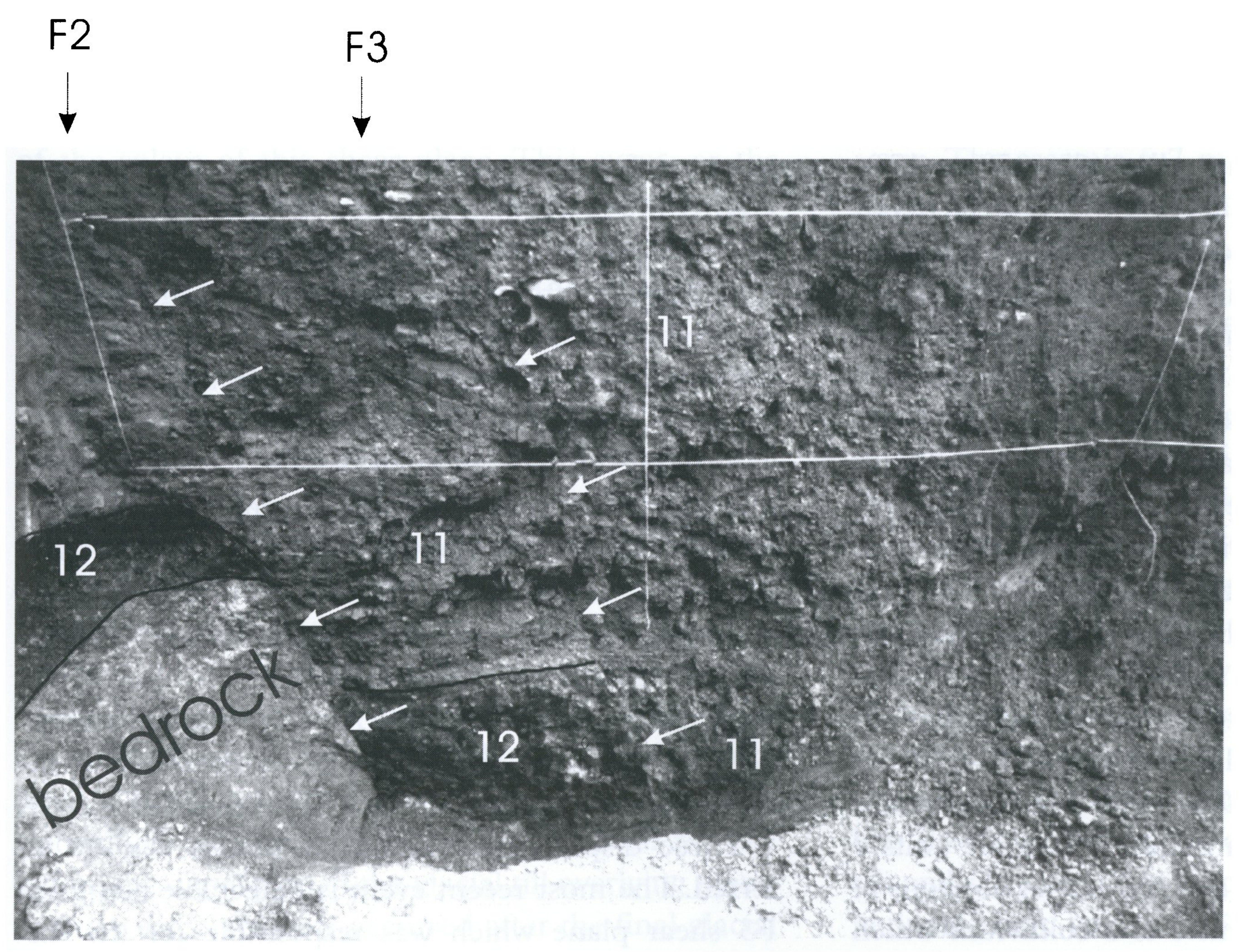

Fig. 8. View of the oldest palesol (unit 12, radiocarbon dated at $23290 \pm 520 \mathrm{BP}$ ) exposed in the trench excavated at the Alpe Troena site. The paleosol was displaced by SE-dipping shear planes (indicated by arrows). Fn, shear planes reported in Fig. 6. 

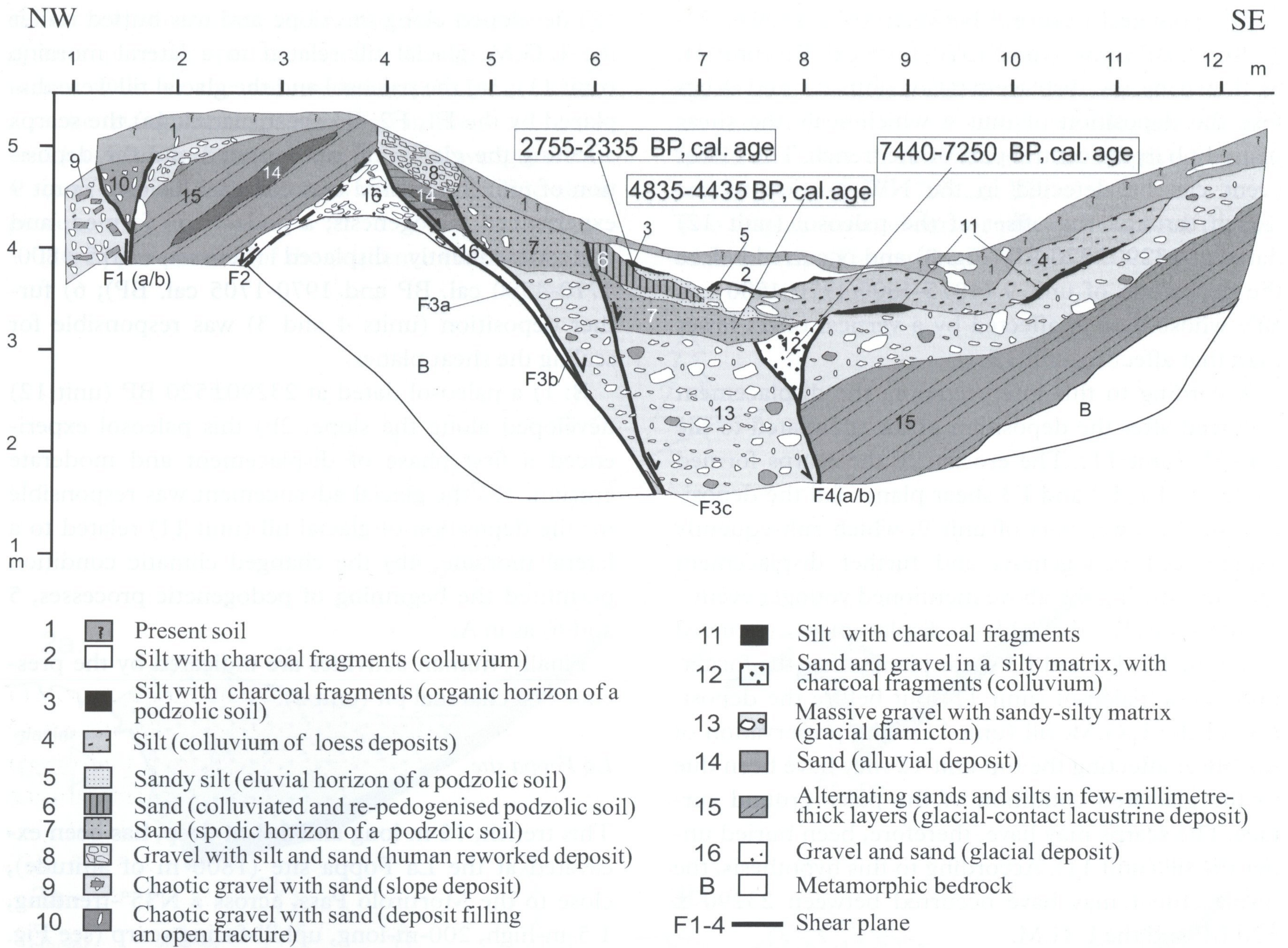

Fig. 9. Log of the trench ( $N$ wall) excavated at the La Foppa site. Three displacement events have been detected at this site: the oldest occurred before the Last Glacial Maximum, the second event may have occurred close to 7440-7250 cal. BP, while the youngest occurred between 4835-4435 cal. BP and 2755-2335 cal. BP.

were exposed in the trench wall reported in Figure 9.

Unit 15 is a thick glacial-contact lacustrine deposit, made of few-millimetre-thick sandy-silty layers, steeply dipping towards the valley (dip $35^{\circ}$ to $45^{\circ}$ ). Although no dates are available for this unit, its deposition is probably related to the L.G.M. The till underlying this unit (16 in Fig. 9) is, indeed, related to the L.G.M., since it does not present the significant weathering features which are typical of pre-L.G.M. glacial deposits. Unit 13 is a further glacial diamicton (related to the L.G.M.) made of massive gravel with sandy-silty matrix. The presence of L.G.M. till units below and over the lacustrine deposits indicates that also unit 15 has to be related to the L.G.M. The high dip values demonstrate that unit 15 experienced a significant tilting.

Units 1 to 12 formed after the glacial retreat. Podzol paleosols and a soil colluvium (units 5, 7 and 11) have also been detected. Unit 11 is a soil colluvium probably originated from a podzol soil, while units 7 and 5 represent the spodic and the eluvial horizons of a paleosol, respectively. Unit 6 is a colluvium which originated from unit 7, probably re-deposited from a scarp (which resulted from the movement along the F3c shear plane; Figs. 9 and 10) over the eluvial horizon (unit 5).

After the re-deposition, a new organic horizon (unit 3) developed over units 4,5 and 6 . Unit 4 is a colluvium originated from loess deposits, as testified by the well rounded clasts of quartz and the Fe-Mn nodules, while unit 2 is a colluvium made of silt with fragments of charcoal and root remains.

A sample was collected for radiocarbon dating from unit 12 (which is a sandy colluvium filling an open fissure) and gave an age of 7440-7250 cal. BP, while the spodic horizon (unit 6) was radiocarbon dated at 4835-4435 cal. BP and the organic horizon (unit 3) gave an age of 2755-2335 cal. BP.

Similarly to the case of the Alpe Troena site, a number of shear planes have been observed affecting the described succession.

Three displacement events or phases can be inferred. The most recent event is detectable along the F3 shear plane which was responsible for the dis- 


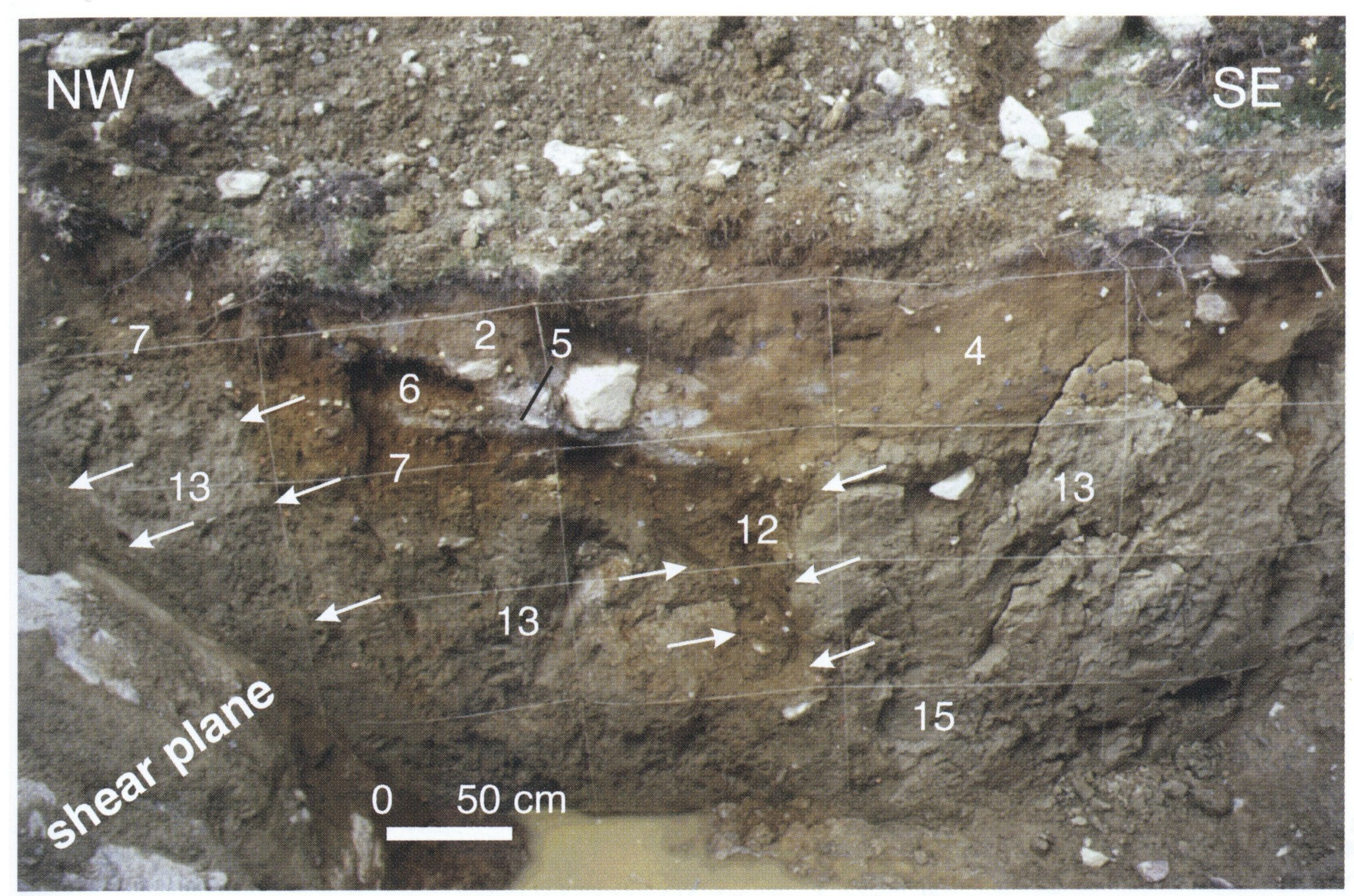

Fig. 10. View of the trench excavated at the La Foppa site. Arrows indicate the shear planes affecting Late Pleistocene-Holocene deposits (see Fig. 9 for further details). Units are numbered as in Fig. 9.

placement of the podzol soil dated at 4835-4435 cal. BP. Moreover, this displacement was probably responsible for the formation of a scarp along the F3c shear plane which fed the re-deposition of the spodic horizon in a colluvial facies (unit 6).

Pedogenesis has developed over the colluvium and unit 3 gives an upper chronological constraint (2755$2335 \mathrm{cal}$. BP) for the colluvial episode and therefore for the displacement. Based on these data, this event occurred between 4835-4435 cal. BP and 2755-2335 cal. BP.

An older event occurred after the L.G.M. and before the formation of the podzol soil (unit 7), as shown by the displacement of unit 13 along the F4 shear plane and by the presence of unit 7 sealing one of the splays of this shear plane. This event, or the youngest event of this displacement phase, may have occurred close to $7440-7250 \mathrm{cal}$. BP, which is the age of the sediment (unit 12) filling the open fissure formed along the F4 shear plane.

The oldest event is indicated by the evident unconformity between units 15 and 13. This testifies to the tilting of the lacustrine deposits (unit 15) before the deposition of the L.G.M. till (unit 13). Considering that unit 15 deposited in a glacial-contact lake related to the L.G.M., the displacement occurred close to this period.

Based on the data collected in the trench, the following evolution can be hypotesised (Fig. 11): 1. the glacier and the till related to a lateral moraine confined a small lacustrine basin; 2. lacustrine deposits were tilted (probably during a minor glacial retreat) before the deposition of the glacial till overlying them; 3. some displacements occurred after the final glacial retreat and were responsible for the displacement of the till and for further deformation in the lacustrine deposits before 4835-4435 cal. BP; 4. a podzol soil developed after the displacements occurred during phase 3 (4a) and was subsequently displaced (between 4835-4435 cal. BP and 2755-2335 cal. BP) (4b), colluvial deposition occurred inside the depression; 5 . colluvial unit 2 deposited after the displacement.

\section{Mortirolo 1 site}

This trench, $14 \mathrm{~m}$ long and up to $3 \mathrm{~m}$ deep, has been excavated close to the Mortirolo Pass, at $1860 \mathrm{~m}$ of altitude, across a $\mathrm{N} 50^{\circ}$-trending downhill-facing scarp. The scarp is 6-7 $\mathrm{m}$ high, $250 \mathrm{~m}$ long, and resulted from the movement along shear planes dipping towards the valley (see Fig. 2 for location).

The trench wall (Figs. 12 and 13) showed some parallel shear planes affecting the metamorphic bedrock, and a main shear plane (F2) dipping $75^{\circ}$ towards NW and placing the metamorphic bedrock (in a pink weathered facies) in contact with continental deposits (units 12 and 13 in Fig. 12) of debris flow facies, related to a polygenic alluvial fan. The form of the fan indicates that these deposits were fed by a minor relief to the SW and that the flow direction was parallel to and confined by the investigated scarp. The alluvial fan did not experience modelling after its deposition, thus suggesting a post-L.G.M. age. A succession of Late Pleistocene-Holocene slope and debris flow deposits (made of fine gravel, sand, sandysilt and silt with scattered clasts; units 1-10 in Fig. 12) and paleosols (units 2,5 and 11), seals the shear 

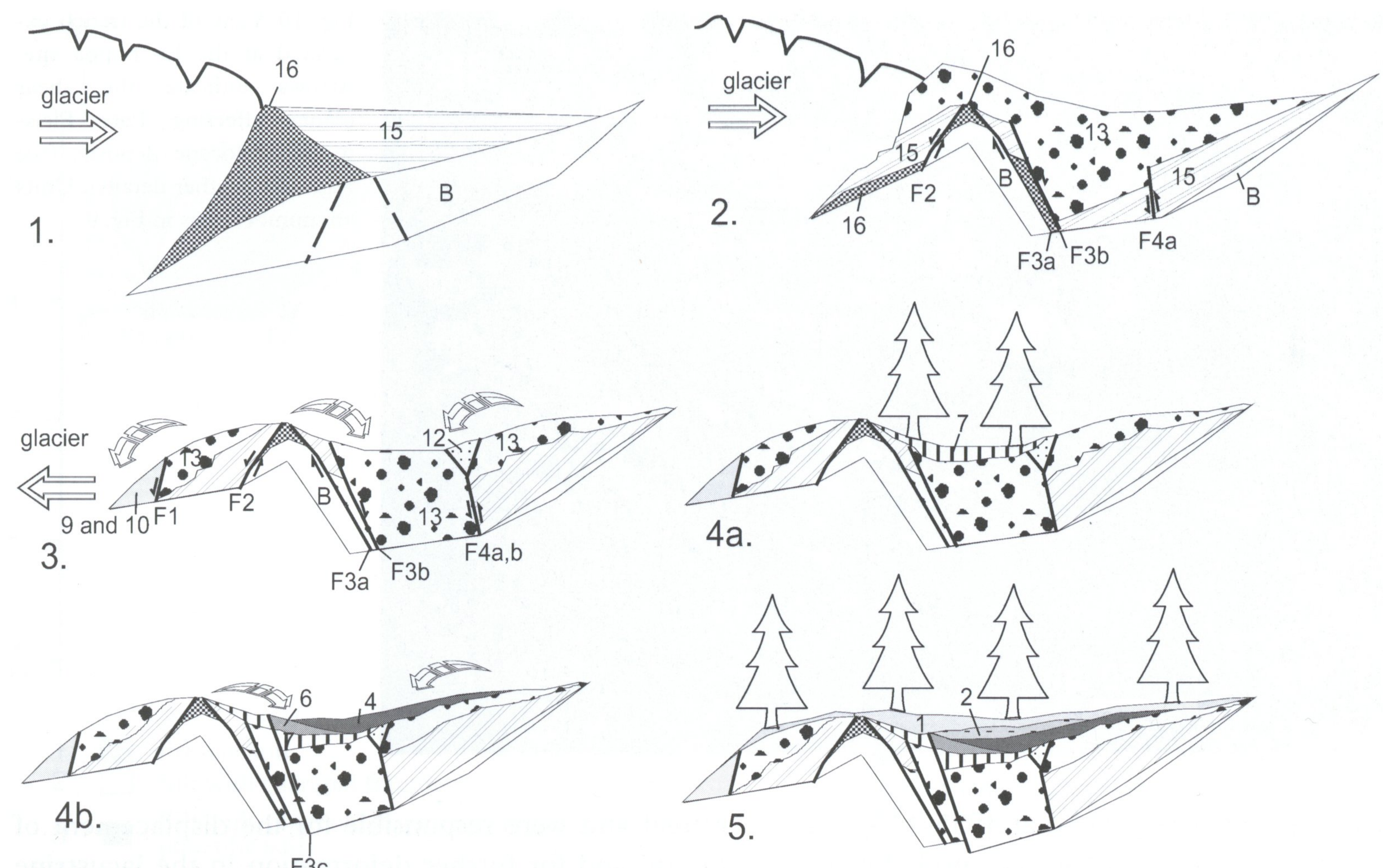

Fig. 11. Evolution of the deformation at the La Foppa site (see text for explanation). Fn, shear planes as reported in Fig. 9. Unit numbering as in Fig. 9.

\section{SE}
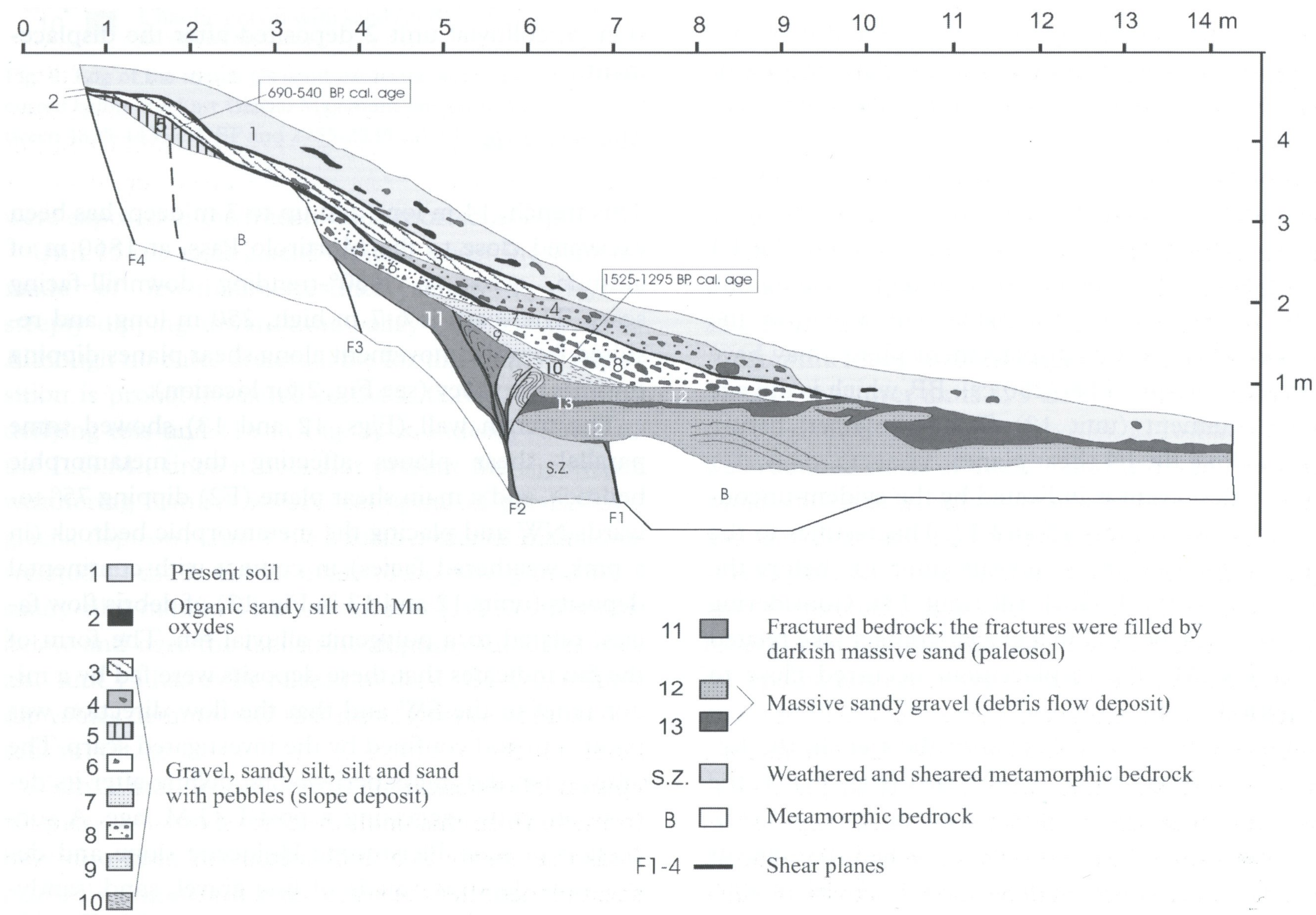

Fig. 12. Log of the trench (W wall) excavated at the Mortirolo 1 site. One displacement event has been detected at this site, responsible for the formation of a 6-7-m-high scarp before 1525-1295 cal. BP. 


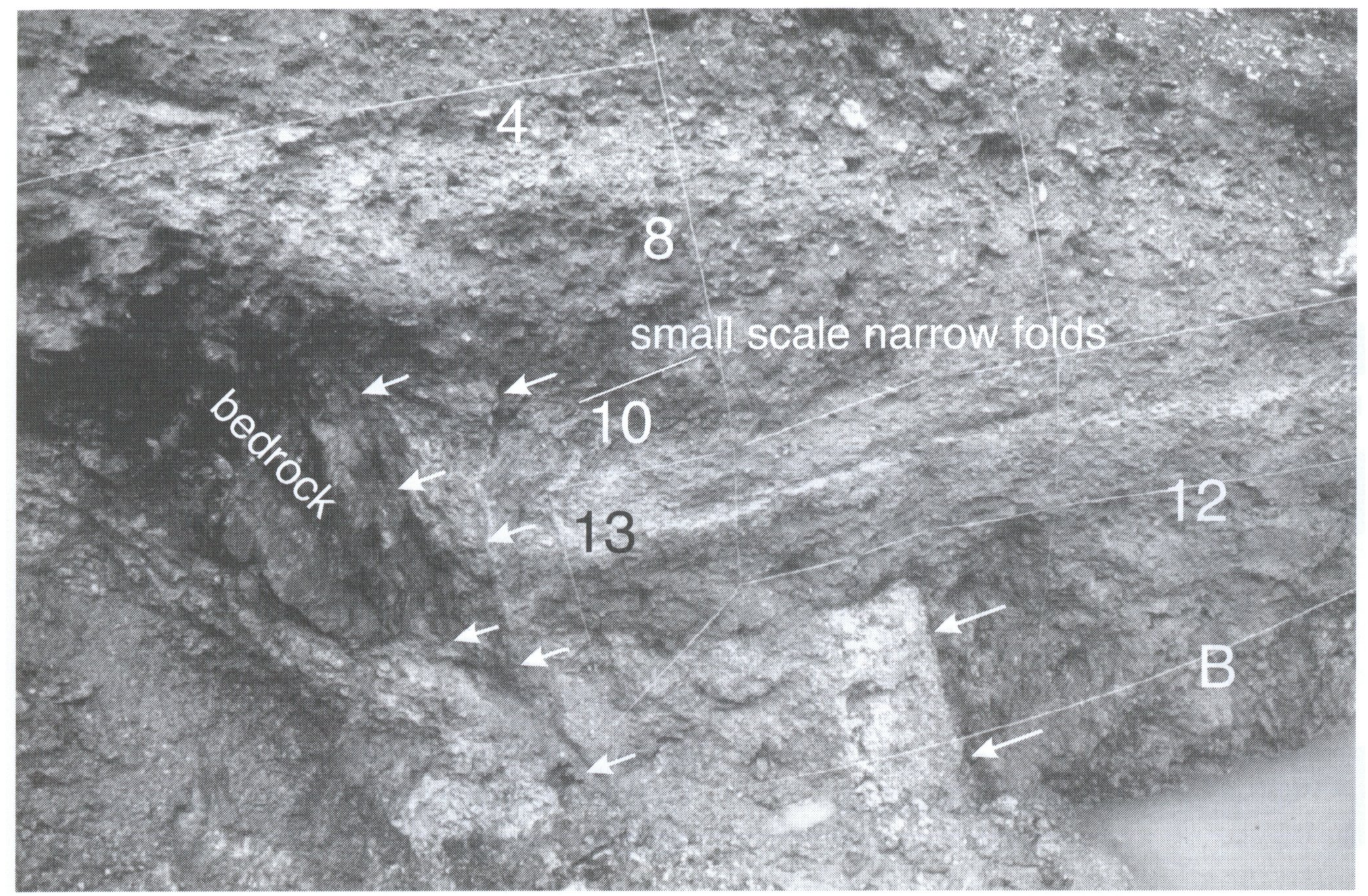

Fig. 13. View of the trench excavated at the Mortirolo 1 site. Arrows indicate the shear planes reported in Fig. 12. Unit numbering as in Fig. 12.

planes affecting both the bedrock and the older debris flow units. This succession is entirely fed by the scarp. Material suitable for dating was supplied by units 10 (1525-1295 cal.BP) and 2 (690-540 cal. BP).

The F2 shear plane splits into three minor diverging splays towards the ground surface (Fig. 12), thus forming a sort of flower structure along which the weathered bedrock and units 12 and 13 have been deformed and displaced. The deformation resulted in small-scale narrow isoclinal folds formed by the complete re-orientation of small flakes of metamorphic bedrock along the shear planes. The height of the scarp (6-7 $\mathrm{m}$ ) yields an indication of the minimum vertical offset related to the activation of the shear planes observed in the trench.

The displacements occurred before 1525-1295 cal. BP (age of unit 10, sealing the shear planes; Fig. 12). No other chronological constraints are available, since the debris flow deposits involved in the deformation did not provide material suitable for dating.

The absence of displaced scarp-derived deposits in the hangingwall is fundamental to define the history of the deformation at this site. As mentioned above, the only deposits affected by the deformation are related to debris flow episodes which originated SW of the investigated site. Scarp-derived deposits followed the activation of the shear planes and seal the displacements. This may indicate that the 6-7-m-high scarp formed suddenly, with a single displacement event, not long before 1525-1295 cal. BP (age of the first unit sealing the shear planes). In consideration of the significant erosional/depositional activity in high mountainous environments following the L.G.M., it is in fact very difficult to assume a progressive scarp formation without deposition related to the scarp retreat. The scarp formation occurred before the deposition of the debris flows (confined by the scarp). These deposits were, in turn, involved in folding along the shear planes.

The cause of the deformation (folding) affecting the debris flow deposits is, however, unclear. This deformation cannot be related to slope creeping responsible for the torsion of the shear planes and folding. The deformation occurred, indeed, in confined conditions, since unit 12 had already deposited when the folds formed and no evidence of slope creeping or solifluxion affects the debris flow deposits (unit 12) in the NW portion of the trench. Therefore, folding of unit 12 and the weathered bedrock has to be related to movements along the shear planes.

The isoclinal geometry of the small folds and the complete re-orientation of the metamorphic flakes may suggest the occurrence of slow movements. Data from further trenches are, however, necessary to cast light on the possible occurrence of creep deformations along the investigated shear plane.

Folding of the weathered bedrock and unit 12 testifies to the occurrence of two displacement events before 1525-1295 cal. BP. The lack of deposits related to the scarp retreat below unit 12 indicates that these two events probably occurred at about the same time, close to the mentioned age (related to the first episode of deposition fed by the scarp, sealing the deformation). In this light, the formation of the narrow folds may testify to a final accommodation along the shear planes after the scarp formation.

Collected data permit to define the site history reported in Figure 14:1) activity along the shear planes 

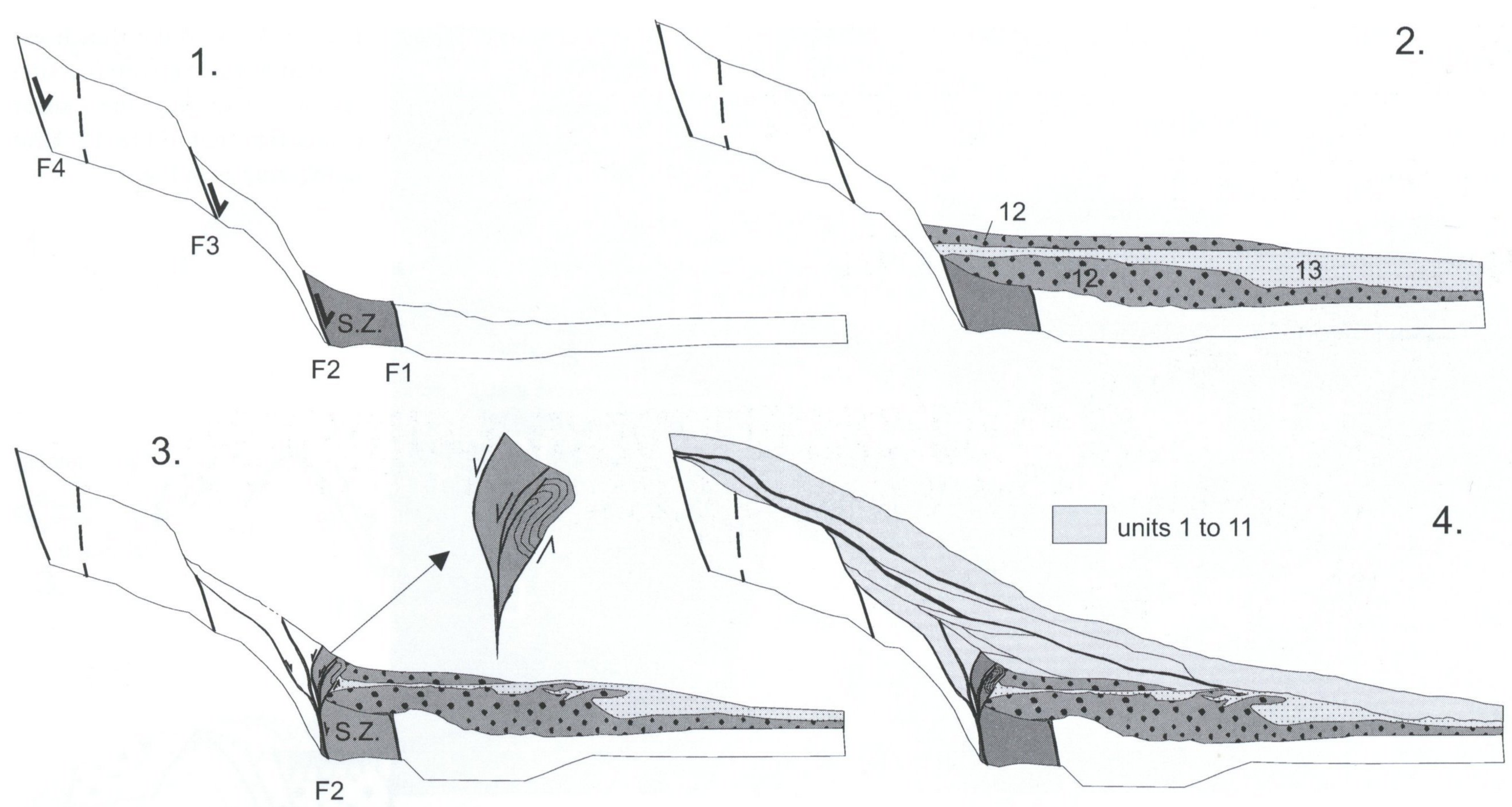

Fig. 14. Evolution of the deformation at the Mortirolo 1 site (see text for explanation). S.Z., shear zone; Fn, shear planes as reported in Fig. 12. Unit numbering as in Fig. 12.

was responsible for the formation of the 6-7-m-high scarp; 2) the displacements were followed by the deposition of debris flow deposits (units 12 and 13); 3) these deposits were involved in folding detectable along the splays of the main shear plane F2; 4) scarpderived deposits have finally sealed the shear planes since 1525-1295 cal. BP.

\section{Mortirolo 2 site}

This trench has been excavated at the Mortirolo Pass, across a N40 ${ }^{\circ}$-trending, $1.5-\mathrm{m}$-high and $100-\mathrm{m}$-long scarp facing towards the mountain (see Fig. 2 for location).

The trench wall (Fig. 15) showed two shear planes (one of them split into two splays), placing the metamorphic bedrock in subvertical contact with a thin sequence of continental deposits. Although this trench is located just $100 \mathrm{~m}$ north of the previously described trench, the sedimentary sequence is completely different, being prevalently made of glacial deposits (unit 7 in Fig. 15) related to the L.G.M. The presence of a well selected sandy horizon at the base of the scarp suggests a subglacial fusion origin of this unit. After the deposition of unit 7, a podzol soil formed, with clearly differentiated spodic (in units 7 and 5), eluvial (unit 4) and organic horizons (unit 3, which has been radiocarbon dated at 1540-1290 cal. $\mathrm{BP})$.

Units 1 and 2 are made of charcoal (related to a charcoal pit excavated some tens of years ago) and gravelly sand with spread fragments of charcoal and roots, respectively.

Unit 5, intercalated between units 7 and 4 at the base of the scarp, is made of heterometric gravel with abundant reddish brown silty-sandy matrix. This unit has been interpreted as a colluvial wedge fed by the scarp, due to the massive facies and its triangular shape. A radiocarbon date has been obtained from the silty-sandy matrix of unit 5 (1810-1540 cal. BP). This age, however, post-date the deposition of this unit, since the deposit experienced subsequent pedogenetic processes. If the interpretation of unit 5 as a colluvial wedge is correct, its deposition identifies an episode of scarp formation and therefore the occurrence of a displacement event. Unit 5 was subsequently displaced, as suggested by the alignment of clasts along the shear plane $\mathrm{F} 2$, and by unit 6 , showing a $20 \mathrm{~cm}$ thick shear zone. This second event occurred before the formation of the organic horizon of the soil (unit 3) sealing the shear planes and radiocarbon dated at 1540-1290 cal. BP.

\section{Discussion}

The investigated deformation can be described as a large mass movement towards the Adda valley, through the activation of the main NW-dipping shear planes, while minor SE-dipping shear planes played the role of antithetic structures.

Trench investigations enabled to collect additional information about the Pleistocene-Holocene sedimentary record and the deformative history. In particular, the subsurface geometry, the kinematics (if 


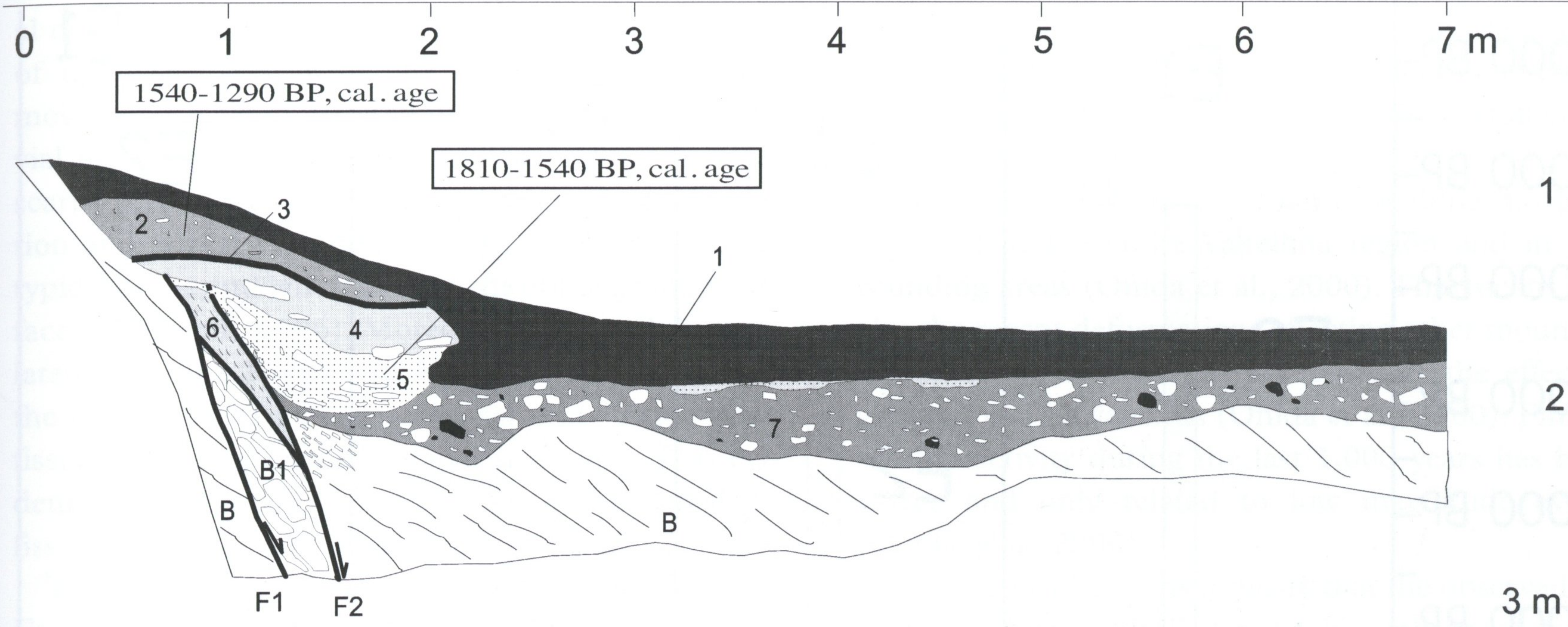
1 Charcoal pit
$2 \quad$ Gravel and sand with charcoal fragments
$3 \square$ Sand (organic horizon of a podzolic soil)
$4 \square$ Sand (eluvial horizon of a podzolic soil)
5 Gravel with sand (spodic horizon of a podzolic soil developed over a colluvium)
$6 \square$ Shear zone affecting both bedrock and deposits
7 Gravel, silt and sand (glacial deposit)
B E Metamorphic bedrock (B1: fractured bedrock)
F1-2/ Shear plane

Fig. 15. Log of the trench (E wall) excavated at the Mortirolo 2 site. Two displacement events have been detected at this site: the youngest one occurred between 1810-1540 cal. BP and 1540-1290 cal. BP, while the oldest event occurred before 1810-1540 cal. BP.

movements are related to creep or stick-slip processes), and the chronology of scarp formation and activity of the shear planes have been defined. Information on these features is fundamental in assessing the hazard related to gravitational movements in the investigated region.

\section{Summary of the displacement events}

The chronology of the displacement events has been summarised in Fig. 16.

Three events have been detected at the La Foppa site: the most recent (E1 in Fig. 16) between 48354435 cal. BP and 2755-2335 cal. BP, the second (E2) between the L.G.M. and 4835-4435 cal. BP (probably close to $7440-7250 \mathrm{cal}$. BP), the oldest (E3) close to the L.G.M.

Two events have been recognised at the Alpe Troena site: the first occurred between 1) $23290 \pm 520 \mathrm{BP}$ and $4875-4800 / 4770-4580$ cal. BP (E2a in Fig. 16) or, alternatively, 2) between $23290 \pm 520 \mathrm{BP}$ and the L.G.M. (E2b); the second (E1) occurred between 4875-4800/4770-4580 cal. BP and 1970-1705 cal. BP. Based on these data, the second displacement event at the Alpe Troena site (E1) is chronologically comparable with the third event which affected the La Foppa site (E1). The first event at the Alpe Troena site may be chronologically comparable with the second event at the La Foppa site (E2) if hypothesis 1) is accepted (event E2a in Fig. 16). Hypothesis 2), i.e. the displacement occurrence inside the interval defined by E2b, would imply a chronological consistency between the first events at both sites.

If these data indicate synchronous activations at the two sites, a quite large portion of the southern slope of the Adda river valley moved suddenly during two different displacement episodes.

Two events have been detected at the Mortirolo 2 


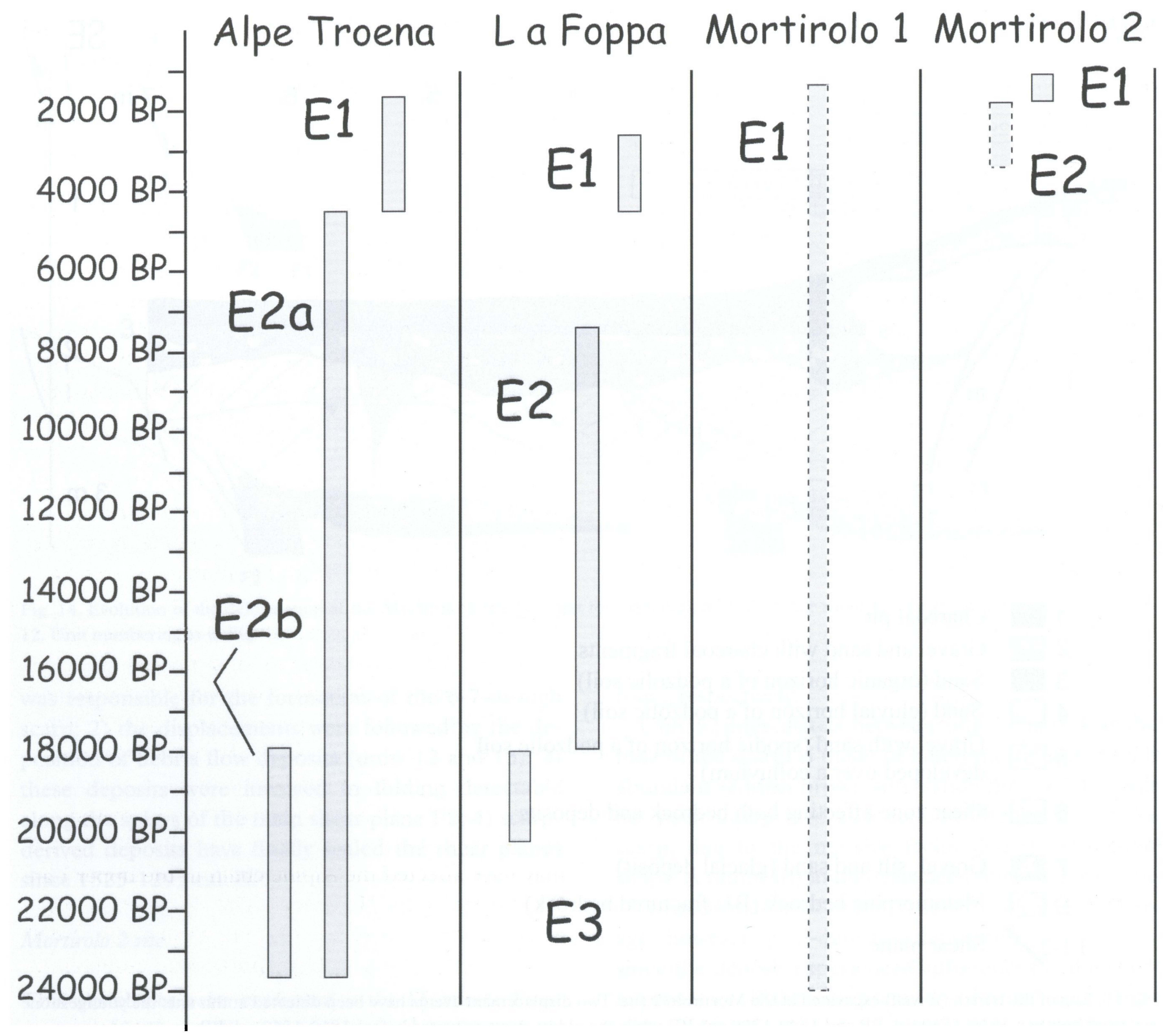

Fig. 16. Chronological intervals during which the displacement events occurred at the Mortirolo Pass area. Dashed lines indicate the lack of a precise displacement chronology. E2a and E2b at the Alpe Troena site are related to two different interpretations of the investigated displacements.

site: the first (E2 in Fig. 16) before 1810-1540 cal. BP and the second (E1) between 1810-1540 cal. BP and 1540-1290 cal. BP.

Only one event (E1 in Fig. 16) probably formed the impressive scarp at the Mortirolo 1 site slightly before 1525-1295 cal. BP. Chronological data are in this case too sparse to permit a correlation between the displacements which affected the two Mortirolo sites.

Finally, chronological data available for the Mortirolo sites show the lack of any evident correlation between the displacements occurred at these sites and those occurred at the La Foppa and Alpe Troena sites (the former being more recent than the latter).

\section{Kinematics}

Available data indicate that the main shear planes dipping towards the Adda valley may have been responsible for the formation of a 6-7-m-high scarp with a single displacement episode. These large displacements may affect all the scarps dipping towards the valley which are usually characterised by impressive heights. A thick undeformed sequence of welldifferentiated coarse slope deposits suggests that this type of deformation has to be considered as inactive since at least 1525-1295 cal. BP (at the Mortirolo 1 site), which is the age of the oldest undeformed unit.

Multiple displacement events have instead been detected along the antithetic shear planes (see Figs. 2 and 3 for the geometrical relationship between 
sinthetic and antithetic shear planes). This suggests that this kind of displacement may represent the usual deformation process responsible for the formation of uphill-facing scarps. The occurrence of sudden movements is demonstrated by the presence of colluvial units (colluvial wedges) related to the retreat of scarps several tens of centimetres high. Scarp formation and retreat are, indeed, considered as processes typical of the sudden displacement of the ground surface (McCalpin, 1996). Moreover, the trench logs related to the La Foppa and Alpe Troena sites showed the deposition of massive colluvial units inside open fissures affecting unconsolidated sediments. This evidence has to be considered as diagnostic of a sudden fissure formation and rapid colluvial filling.

The reconstruction of the site histories at the $\mathrm{La}$ Foppa and Alpe Troena sites (Figs. 7 and 11) shows a direct relationship between slip along shear planes and sedimentation in the scarp-related troughs. The colluvial and debris units filling the depressions may be partly related to erosion/deposition after the topographic changes due to the displacements. In contrast, soil formation indicates periods of inactivity.

Finally, the presence of numerous parallel shear planes over a large portion of the slope affected by Holocene activity hinders the definition of parameters such as the offset per event and the cumulative offset.

\section{Triggering mechanism}

According to the literature (e.g. Radbruch-Hall, 1978; McCalpin \& Irvine, 1995), the stress field responsible for the activation of sackung structures may have different origins: gravitational forces, stored forces related to the loading of an area during glaciation, seismic shaking, and tectonic movements related to the activation of seismogenic structures. The Alpine sackung structures are traditionally attributed to gravitational deformation of the slopes due to: (1) the great energy of the relief caused by the Alpine uplift (e.g. Dramis \& Sorriso-Valvo, 1994); (2) the debuttressing of mountain slopes after the post-L.G.M. retreat of thick glacier covers (e.g. Mortara \& Sorzana, 1987); (3) causative relationships with the recent activity of major faults (Giardino, 1996; Giardino \& Polino, 1997).

The hypothesis whereby the described structures represent the complex surficial expression of seismogenic faults and strong earthquakes may presently play a significant role in triggering the deformations may be ruled out for a number of reasons. First of all, the gravitational origin of the deformations is demonstrated by the huge displacement $(6-7 \mathrm{~m})$ affecting the sinthetic shear plane at the Mortirolo 1 site and by the overall distribution of the shear planes across the slope (Figs. 2 and 3), consistent with the already published models of deep seated gravitational deformations (e.g. Zischinsky, 1966; Radbruch-Hall et al., 1976; Mahr, 1977).

Moreover, no evidence of active faulting has been observed in the entire Valtellina region and in surrounding areas (Onida et al., 2000). This means that also the recent deformations affecting other mountain slopes in the central Alps are probably the effect of gravitational movements (Onida et al., 2000). Finally, seismic activity during the last 1,000 years has been scarce and only related to low magnitude events (Onida et al., 2000).

These considerations indicate that the observed deformations are entirely consistent with gravitational triggering processes, probably conditioned by the debuttressing effect of the glacial retreat. In this light, the evidence of just one displacement event along a main shear plane dipping towards the valley (Mortirolo 1 site) and the repetition of minor displacement events along an antithetic shear plane (Mortirolo 2 site) probably testify to a progressive accommodation along the latter in response to the huge deformation occurred along the former.

A stronger seismicity, induced by an increased tectonic "intensity" related to the post-glacial rebound, may have affected the Alpine chain in the upper Late Pleistocene-early Holocene. The Late Pleistocene glacial retreat (after 18,000 BP; Orombelli, 1983) may have induced a high horizontal compressive stress perpendicular to the retreating ice-limit (Stewart et al., 2000, and references therein), responsible for increasing the stress related to normal tectonic processes. This increase is likely to be responsible for larger slip rates per fault, larger magnitude seismic events and reduced recurrence intervals. The effects of the deglaciation have been documented in areas affected by large ice-caps (such as the Fennoscandia; Wu et al., 1999; Dehls et al., 2000), while contrasting data are available for the Swiss Alps (Schaer \& Jeanrichard, 1974; Gudmunsson, 1994; Beck et al., 1996) and the issue has never been addressed for the Italian Alps.

In the case of the investigated area, however, no evidence of upper Late Pleistocene faulting has been detected. Therefore, if a stronger upper Late Pleistocene seismicity played a role in triggering the observed deformations, it has to be related to seismically active areas adjacent to the Valtellina region (e.g., to the SE, the Lake Garda area). The influence of the possible post-glacial seismicity probably decreased during the Holocene and therefore the latest detected 
displacements occurred in a seismicity regime similar to the present one.

\section{Long-term evolution and effects}

The tragic landslide occurred at Mt. Zandila-Valpola (close to the investigated area) and originated from a sackung structure (Azzoni et al., 1992; Dramis et al., $1995)$ indicates that gravitational deformations affecting huge rock masses can evolve in a paroxistic way with dramatic effects. Deep seated gravitational deformations such as those described for the Mortirolo area are, indeed, responsible for pervasive ruptures affecting large portions of a mountain slope (Figs. 2 and 3 ) thus creating conditions favourable to the occurrence of huge landslides.

Considering that available chronological data indicate a recent activation of the shear planes (1st millennium AD), the Mortirolo sector of the Adda valley may be affected by a significant landslide risk. Therefore, a continuous control of the deformation is augured.

\section{Conclusions}

The excavation of trenches at the Mortirolo Pass (Valtellina region), despite the logistic constraints this technique is subject to in mountainous areas, enabled to collect new information on the kinematics and chronology of the deformation and on the geometry of the shear planes.

The oldest documented deformation episode affected the investigated area close to the L.G.M. (La Foppa and perhaps Alpe Troena sites). Subsequent deformation episodes may have been (at least in one case) synchronous at sites located some $\mathrm{km}$ apart (e.g. Alpe Troena and La Foppa). This may indicate that some displacement events affected more shear planes at the same time in a wide area. In other cases the deformation only affected local sectors of the whole structure. The youngest displacements occurred during the 1 st millennium $\mathrm{AD}$ and therefore the structure cannot be considered as presently inactive.

If the data collected at the four trench sites can be extrapolated to the entire structure, a stick-slip motion (related to brittle displacements) affected both the shear planes dipping towards the mountain (antithetic structures) and those dipping towards the valley.

The kinematics and geometry of the investigated shear planes indicate that the observed deformations are consistent with gravitational forces. Therefore, the climatic history and geomorphic evolution of the
Alpine chain represent the main factors which conditioned the re-activation of pre-existing structures. Displacements occurred in the upper Late Pleistocene may have been conditioned by the increased seismicity which possibly affected the Alpine area after the L.G.M. (as a result of the post-glacial rebound). The lack of active faults in the investigated area indicates that earthquakes which may have triggered the displacements originated in areas adjacent to the Valtellina region (e.g., the Lake Garda area, to the SE). The latest detected displacements probably occurred in a seismicity regime no longer affected by the deglaciation processes and therefore similar to the present one, characterised by sparse low-magnitude events.

The investigations at the Mortirolo Pass have shown that the application of paleoseismological techniques allows to collect quantitative data on the kinematics and chronology of large scale gravitational movements. Therefore, such investigations should be performed along other sackung structures in order to define a reliable dataset which may be used in hazard evaluations.

\section{Acknowledgments}

The work has been supported by the EC DG XII (project ENV4-CT97-0578), by CNR, Istituto di Ricerca sulla Tettonica Recente and by CNR, Centro di Studio per la Geodinamica Alpina e Quaternaria.

We are grateful to C. Ravazzi (CNR, Centro di Studio per la Geodinamica Alpina e Quaternaria), F. Previtali, and R. Comolli (Department of Environmental Sciences, University of Milano-Bicocca) for the fruitful discussions in the field and for the chemical analyses of the soils. Many thanks also to M. Cremaschi, L. Trombino and A. Bini (Department of Earth Sciences, University of Milano) for the micromorphological analyses of the soils and the field discussions about the geomorphological setting of the investigated area. The reviews by $M$. Cushing, S. Baize and an anonymous referee improved the original manuscript.

\section{References}

Azzoni, A., Chiesa, S., Frassoni, A. \& Govi, M., 1992. The Valpola landslide. Engineering Geology 33: 59-70.

Beck, A.C., 1968. Gravity faulting as a mechanism of topographic adjustement. New Zealand Journal of Geology and Geophysics 11: 191-199.

Beck, C., Manalt, F., Chapron, E., Van Rensbergen, P. \& De Batist, M., 1996. Enhanced seismicity in the Post-Glacial period: evidence from the Post-Würm sediments of Lake Annecy, northwestern Alps. Journal of Geodynamics 22: 155-171.

Bini, A., Cita, M.B. \& Gaetani, M., 1978. Southern Alpine lakes Hypothesis of an erosional origin related to the Messinian entrenchment. Marine Geology 27: 271-288. 
Castellarin, A., Fesce, A.M., Picotti, V., Pini, G.A., Prosser, G., Sartori, R., Selli, L., Cantelli, L. \& Ricci, R., 1987. Structural and kinematic analysis of the Giudicarie deformation belt. Implications for compressional tectonics of Southern Alps. Mineralogica Petrografica Acta 30: 287-310.

Cremaschi, M. \& Rodolfi, G., 1991. Il suolo. Pedologia nelle scienze della terra e nella valutazione del territorio. Roma: $427 \mathrm{pp}$.

Dehls, J.F., Olesen, O., Olsen, L. \& Blikra, L.H., 2000. Neotectonic faulting in northern Norway; the Stuoragurra and Nordmannvikdalen postglacial faults. Quaternary Science Reviews 19:1447-1460.

Dramis, F. \& Sorriso-Valvo, M., 1994. Deep seated slope deformations, related landslides and tectonics. Engineering Geology 38: 231-243.

Dramis, F., Govi, M., Guglielmin, M. \& Mortara, G., 1995. Mountain Permafrost and Slope Instability in the Italian Alps. Permafrost and Periglacial Processes 6: 73-81.

Felber, M., Frei, W. \& Heitzmann, P., 1991. Seismic evidence of pre-Pliocene valley formation near Novazzano (Ticino,Switzerland). Eclogae geologica Helvetia 84: 753-761.

Finck, P., 1978. Are southern Alpine lakes former Messinian canyons? Geophysical evidence for preglacial erosion in the southern lakes. Marine Geology 27: 289-302.

Forcella, F., 1984. The Sackung between Mount Padrio and Mount Varadega, Central Alps, Italy: a remarkable example of slope gravitational tectonics. Mèditerranèe 51: 81-92.

Forcella, F., Onida, M., \& Tibaldi, A., 1998. Risultati preliminari di un'indagine di tipo paleosismologico applicata allo studio di deformazioni recenti in ambiente alpino, alta Valtellina (Alpi Centrali, Italia). Geologia Insubrica 3: 63-72.

Froitzheim, N., Schmid, St. \& Conti, P., 1994. Repeated change from crustal shortening to orogen-parallel extension in the Australpine units of Graubünden. Eclogae geologica Helvetia 87: 559-612.

Giardino, M., 1996. Aspetti metodologici e problemi cartografici dello studio di deformazioni superficiali nella media Valle d'Aosta. Il Quaternario 9: 227-232.

Giardino, M. \& Polino, R., 1997. Le deformazioni di versante dell'alta valle di Susa: risposta pellicolare dell'evoluzione tettonica recente. Il Quaternario 10: 293-298.

Gudmundsson, G.H., 1994. An order-of-magnitude estimate of the current uplift-rates in Switzerland caused by the Würm Alpine deglaciation. Eclogae Geologicae Helvetiae 87: 545-557.

Laubscher, H.P., 1988. Material balance in Alpine orogeny. Bulletin of the Geological Society of America 100: 1313-1328.

Mahr, T., 1977. Deep-reaching gravitational deformations of high mountain slopes. Bulletin of the International Association of Engineering Geology 16: 121-127.
McCalpin, J., 1996. Paleoseimology. Academic Press, San Diego: $588 \mathrm{pp}$.

McCalpin, J.P. \& Irvine, J.R., 1995. Sackungen at the Aspen highlands Ski Area, Pitkin County, Colorado. Environmental and Engineering Geoscience 1: 277-290.

Mortara, G. \& Sorzana, P.F., 1987. Fenomeni di deformazione gravitativa profonda nell'arco alpino occidentale italiano. Considerazioni lito-strutturali e morfologiche. Bollettino della Società Geologica Italiana 106: 303-314.

Onida, M., Mirto, C., Stucchi, M., Galadini, F. \& Leschiutta, I., 2000b. Tettonica attiva e sismicità nelle Alpi Centrali. In: Galadini, F., Meletti, C. \& Rebez, A. (eds.): Ricerche del GNDT nel campo della pericolosità sismica (1996-1999). Special Publication of CNR-GNDT, Gruppo Nazionale per la Difesa dai Terremoti, Roma: 93-104.

Orombelli, G., 1983. Il Pleistocene superiore in Italia - I depositi glaciali. Geografia Fisica e Dinamica Quaternaria 6: 179-180.

Radbruch-Hall, D., 1978. Gravitational creep of rock masses on slopes. In: B. Voight (Ed.). Rockslides and Avalanches, 1. Developments in Geotechnical Engineering. Elsevier, Amsterdam: 607-657.

Radbruch-Hall, D., Varnes, D.J. \& Savage, W.Z., 1976. Gravitational spreading of steep-sided ridges ("Sackung") in Western United States. Bulletin of the International Association of Engineering Geology 14: 23-35.

Schaer, J.P. \& Jeanrichard, F., 1974. Mouvements varticaux anciens et actuels dans les Alpes suisses. Eclogae Geologicae Helvetiae 67: 101-119.

Sorriso-Valvo, M., 1995. Considerazioni sul limite tra deformazione gravitativa profonda di versante e frana. Memorie della Società Geologica Italiana 50: 179-185.

Stewart, I.S., Sauber, J. \& Rose, J., 2000. Glacio-seismotectonics: ice sheets, crustal deformation and seismicity. Quaternary Science Reviews 19: 1367-1389.

Stuiver, M., Reimer, P.J., Bard, E., Beck, J.W., Burr, G.S., Hughen, K.A., Kromer, B., McCormac, G., van der Plicht, J. \& Spurk, M., 1998. INTCAL98 Radiocarbon Age Calibration, 24,000-0 cal BP. Radiocarbon 40: 1041-1084.

Working Group CPTI, 1999. Catalogo parametrico dei terremoti italiani. ING, GNDT, SGA SSN, Bologna: 92 pp.

Wu, P., Johnston, P. \& Lambeck, K., 1999. Postglacial rebound and fault instability in Fennoscandia. Geophysical Journal International 139: 657-670.

Zischinsky, U., 1966. On the deformation of high slopes. In: Proceedings of the lst Conference of the International Society of Rock Mechanics, Lisbon: 179-185. 